\title{
Cultural evolution in Vietnam's early 20th century: A Bayesian networks analysis of Hanoi Franco-Chinese house designs
}

\author{
Quan-Hoang Vuong ${ }^{\text {a,b, }}$, Quang-Khiem Bui ${ }^{c}$, Viet-Phuong La ${ }^{\text {a,b }}$, Thu-Trang Vuong ${ }^{\mathrm{d}}$, \\ Manh-Toan Ho ${ }^{a, b}$, , Hong-Kong T. Nguyen ${ }^{\text {e }}$, Hong-Ngoc Nguyen ${ }^{\mathrm{f}}$, Kien-Cuong P. Nghiem ${ }^{g}$, \\ Manh-Tung Ho ${ }^{\text {a, h, i, * }}$
}

${ }^{a}$ Centre for Interdisciplinary Social Research, Phenikaa University, Yen Nghia Ward, Ha Dong District, Hanoi, 100803, Viet Nam

${ }^{\mathrm{b}}$ Faculty of Economics and Finance, Phenikaa University, Yen Nghia Ward, Ha Dong District, Hanoi, 100803, Viet Nam

${ }^{c}$ Hanoi College of Arts, 7 Hai Ba Trung Street, Hoan Kiem District, Hanoi, 100000, Viet Nam

${ }^{\mathrm{d}}$ Sciences Po Paris, Campus de Dijon, 21000, Dijon, France

${ }^{\mathrm{e}}$ A.I. for Social Data Lab, Vuong \& Associates, 3/161 Thinh Quang, Dong Da District, Hanoi, 100000, Viet Nam

${ }^{\mathrm{f}}$ Ho Chi Minh City University of Fine Arts, Ho Chi Minh City, Viet Nam

${ }^{g}$ Vietnam-Germany Hospital, 16 Phu Doan Street, Hoan Kiem District, Hanoi, 100000, Viet Nam

${ }^{\mathrm{h}}$ Vietnam Academy of Social Sciences, Institute of Philosophy, 59 Lang Ha Street, Ba Dinh District, Hanoi, 100000, Viet Nam

${ }^{\text {i }}$ Ritsumeikan Asia Pacific University, Graduate School of Asia Pacific Studies, Oita Prefecture, 874-8577, Japan

\section{A R T I C L E I N F O}

This work is dedicated to the late professor André Farber (1943-2017) of l'Université Libre de Bruxelles.

\section{Keywords:}

Cultural evolution

Hanoi architecture

old quarter

House façade

Buddhism

Franco-Chinese style

French colonialism

Bayesian network

Hamiltonian Markov chain Monte Carlo

\begin{abstract}
A B S T R A C T
The study of cultural evolution has taken on an increasingly interdisciplinary and diverse approach in explicating phenomena of cultural transmission and adoptions. Inspired by this computational movement, this study uses Bayesian networks analysis, combining both the frequentist and the Hamiltonian Markov chain Monte Carlo (MCMC) approach, to investigate the highly representative elements in the cultural evolution of a Vietnamese city's architecture in the early 20th century. With a focus on the façade design of 68 old houses in Hanoi's Old Quarter (based on 248 photos and 78 data lines), the study argues that it is plausible to look at the aesthetics, architecture, and designs of the house façade to find traces of cultural evolution in Vietnam, which went through more than six decades of French colonization and centuries of sociocultural influence from China. The in-depth technical analysis, though refuting the presumed model on the probabilistic dependency among the variables, yields several results, the most notable of which is the strong influence of Buddhism over the decorations of the house façade. Particularly, in the top 5 networks with the best Bayesian Information Criterion (BIC) scores and small $p$-values, the variable for decorations (DC) always has a direct probabilistic dependency on the variable B for Buddhism. The paper then discusses these findings and suggests integrating Bayesian statistics in social sciences in general and for studies of cultural evolution and architectural transformation in particular.
\end{abstract}

\section{Introduction}

"Les temples et les Bouddhas de pierre pour mes pères

Les femmes courbées dans les rizières pour mes mères

Dans la prière, dans la lumière, revoir mes frères

Toucher mon arbre, mes racines, ma terre ..."

- "Bonjour Vietnam” by Marc Lavoine
The application of Bayesian analysis could foster a stronger and more unified framework for social scientific statistical practice (Gill, 2002; Jackman, 2000, 2009). In the Bayesian methods, because all unknown quantities are treated probabilistically, researchers are positioned to be more cautious and prudent in evaluating the evidence of an effect, avoiding the trap of overestimating effects, or more dangerously, committing logical inconsistencies (Gill, 2002; Kruschke, 2015; McElreath, 2016). The temporal dynamics of observable data in social sciences make the field particularly suitable for Bayesian analysis, which does not assume having infinite amounts of forthcoming data. As such, social scientists can update prior distributions by conditioning on newly

\footnotetext{
* Corresponding authors. Centre for Interdisciplinary Social Research, Phenikaa University, Yen Nghia Ward, Ha Dong District, Hanoi, 100803, Viet Nam.

E-mail addresses: hoang.vuongquan@phenikaa-uni.edu.vn (Q.-H. Vuong), tung.homanh@phenikaa-uni.edu.vn (M.-T. Ho).
} 
observed data (Gill, 2002), and refine their inferences when being explicit about estimation biases (Malakoff, 1999). While researchers of archeology and sociology are indeed turning to the Bayesian approach to systematically include qualitative, narrative, and intuitive knowledge into statistical models (Crema, Edinborough, Kerig, \& Shennan, 2014; Dediu, 2009; Griffiths \& Kalish, 2007; Matthews, Tehrani, Jordan, Collard, \& Nunn, 2011; Oinonen et al., 2014; Pagel \& Meade, 2005, 2006; Perreault, Moya, \& Boyd, 2012; Reali \& Griffiths Thomas, 2010; Riede \& Edinborough, 2012), the method remains in obscurity among social scientists in Vietnam, where research methodologies are either qualitative or quantitative based on the classical statistical approaches. In an attempt to demonstrate the applicability of Bayesian analysis in the social sciences in general and in the field of cultural evolution in particular, this study seeks to break down the architectural evolution of a Vietnamese city in the early 20th century. The case study will shed light on: (i) how a rigorous Bayesian networks analysis is carried out using a rather small volume of data, (ii) how the presumed model of a social science research may be dismissed to give way for unexpected but insightful results, and notably, (iii) how researchers in societies with similarly syncretic or hybrid behaviors, either due to colonialism or imperialism, could apply this perspective and method to analyze these features.

Showcasing the merits of the Bayesian technique aside, this study also seeks to study cultural evolution from a perspective - the architectural evolution and its underlying influencing elements - unlike much of the extant literature. The scholarship on cultural evolution addresses the issues surrounding the adaptive cultural processes that result from the cognitive details of human social learning and inference (Boyd and Richerson, 1996; Henrich, 2004; Henrich \& McElreath, 2003). Within this field, researchers are often divided into two camps, one espousing for taking evolutionary biology as a reference point to illustrate the Darwinian evolutionary properties of human culture (Boyd \& Richerson, 1985; Cavalli-Sforza \& Feldman, 1981; Mesoudi, Whiten, \& Laland, 2006; Youngblood \& Lahti, 2018), and the other refusing to simplify modes of cultural transmission by use of analogy with modes of genetic transmission because the two domains do not share the same properties (Blackmore, 2006; Claidière \& André, 2012; Dennett \& McKay, 2006; Fuentes, 2006; Mulder, McElreath, \& Schroeder, 2006). While this kind of debate may go on, it has become clear that this interdisciplinary field has rich insights on the ways human beings behave over time.

In this regard, the current research adds to the literature on architectural evolution, such as on the rural cemetery of the Anglo-American (Schuyler, 1984), the Soviet structures under Stalin (Paperny, 2002), the distribution of Egyptian military bases over time and across borders (Ellen, 2004), the wooden long-houses on the Pacific Northwest coast (Jordan \& O'Neill, 2010). More importantly, it underlines the slow pace at which cultural evolution occurs - that practices and artifacts recorded in social anthropology and history were the results of years, decades, and even centuries of influence and transformation. As large-scale architecture has the power to stir up "romantic nostalgia for a lost world in which one has not participated, but which might be imagined or scientifically resurrected" (Houston, 1998, p. vii), in examining the evolving house front designs in the old streets of Hanoi, the study aims to evoke a meaningful discussion on the intertwined relationship between a longing for the past and a yearning for modernization. The nostalgia is best captured in the paintings of old Hanoi streets by the Vietnamese artist Bui Xuan Phai, whose name is synonymous with oil paintings about bygone Hanoi Old Quarter_-"Phố Phái” (literally, "Street Phai") (Taylor, 1999). Bui Xuan Phai (1920-1988) is one of the "Four Pillars" of Vietnamese paintings, belonging to the realm of folklore and myth (Naziree, 2006; Taylor, 1999; Thai, 1994). "Phố Phái," originated from the early 1960s (TT\&VH, 2010), implies not just the Vietnamese respect for a great artist but also a symbol of aesthetics in the Vietnamese souls. Fig. 1 is an example of "Phố Phái" - the brown brick roofs, the whitewashed walls, the black undecorated windows, and the nearly empty narrow streets and alleys.

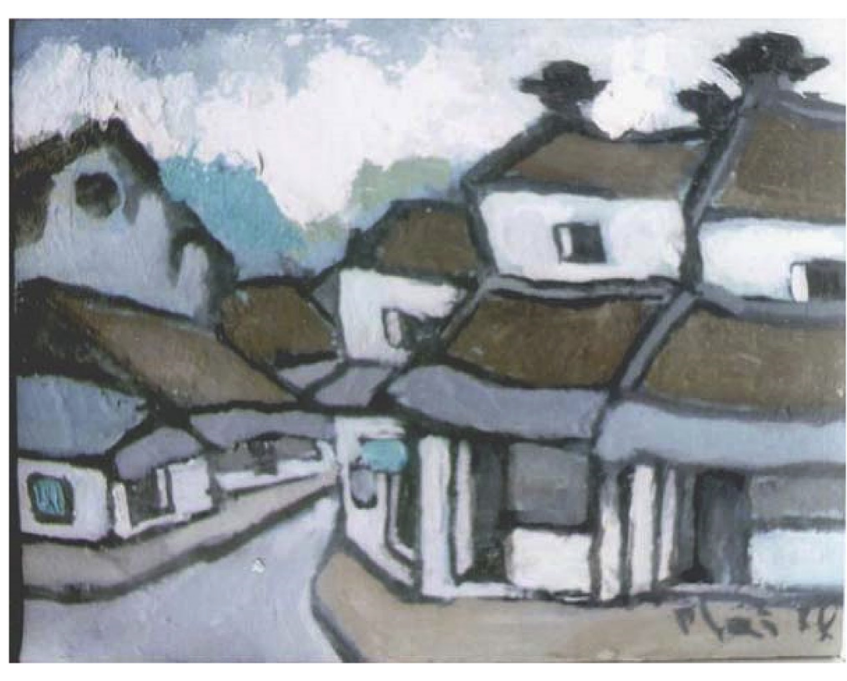

Fig. 1. A painting of Hanoi Street by Bui Xuan Phai (2012).

These paintings have captured the very essence of what is known in Vietnam as the "tube house" ("nhà ông")—-traditionally attached street houses whose widths are narrow while their lengths are very long (Kien, 2008a; b). This research, inspired by "Phố Phái" and the cultural-historical continuity as reflected in Hanoi architecture, will delve into the elements of cultural and religious influences in the house designs, especially the façade. More importantly, the research situates itself amid the rapid urbanization and commercialization in Vietnam as it tries to capture the old fragments of the capital city. Many old houses in Hanoi are being changed and may not stand the test of time. The internal structure of the houses would make for an interesting inquiry, but the research's focus on the house façade alone is driven by the principal concern over "face" in Confucian society. In other words, the front of house reflects the face of the family, and therefore, its culture. As Vuong et al. (2018b) have shown, the "cultural additivity" in Vietnamese architecture is reflected in the front of a house in the co-existence of French-styled columns, Confucian scrolls, the Taoist yin-yang sign, and the Buddhist lotus sculpture. The statistical analysis, therefore, will show how French and Chinese cultures have influenced the designs of the old houses in Hanoi.

\subsection{Research questions}

This research sets out to answer the following two questions:

RQ1 Is it plausible to look at the aesthetics, architecture, and designs of the house façade in Hanoi to find traces of cultural evolution in the early 20th century in Vietnam, which went through more than six decades of French colonization and centuries of sociocultural influence from China?

RQ2 What are the most notable elements that affect the perception of cultural evolution of Vietnamese people who are familiar with or have been exposed regularly to this type of architecture and cultural behavior?

\section{Literature review}

\subsection{Franco-Chinese aesthetics and architecture in Vietnam}

Given the cultural specificity of this study, it is important first to be familiar with the aesthetics and architectural history of Vietnam and Hanoi. French troops captured the citadel of Gia Dinh in 1859, defeating the last Vietnamese dynasty Nguyen and paving the way for its establishment of French Indochina (initially comprising Annam, Tonkin, and Cochinchina) in 1887. Under French imperialism, the Cornudet Law that 
was passed by its government in 1919 stipulated the rules for urban planning and development in its colonies, such that contemporary Western construction techniques would take into account the native aesthetics and humid tropical climate (Le, 2013; Nguyen, 2014; Vongvilay, Shin, Kang, Kim, \& Choi, 2015). This style, made famous by the French architect Ernest Hebrard, comes to be known as the Indochine style-which is an effortless fusion of traditional Vietnamese and grand European elements for both aesthetics and practical purposes (Le, 2013).

According to Nguyen (2014), the development of Indochinese architecture peaked in Vietnam in 1920-1945 and waned in the 1960s. In the post-1945 period, the designs were either filled with nostalgia and longing for traditions or touched with some stroke of creativity from the internationalization trend at the time (Nguyen, 2014). In a slightly different account, Herbelin (2016) argues that this movement took place in 1920-1930, with one wave of affluent Vietnamese people building houses entirely in the footsteps of the French and another pursuing a more modern style incorporating northern Vietnamese decorative elements. However, the architectural fusion, which used both indigenous construction materials such as bamboo, wood, hut, mud and metropolitan materials such as iron, concrete, tiles, and bricks, turned out to be costly and only those very wealthy could afford it (Herbelin, 2016).

In the past decade, there have been many monumental works on the French architecture and urban planning in Vietnam, particularly the Indochine style seen in Hanoi and Saigon (now Ho Chi Minh City). For example, Tran and Nguyen (2012) have provided a meticulous and comprehensive work on the legacy of French architecture in Hanoi, documenting the changing cityscape from as early as the mid-nineteenth century and comparing it with the construction of Indochine houses in Saigon in the early twentieth century. Walker (2011), together with photographer Jay Graham, has published over 300 colored photos of the architecture, furniture, and handicrafts in Vietnam, Laos, and Cambodia, drawing insights into the combined influence of Indian, Chinese and French traditions in this region. More recently, Herbelin (2016) has taken a contrarian view by pointing out that the Indochine style was not entirely successful due to its high cost, which prompted the French to return to its classical design, such as in the case of the then Ministry of Finance (1927) and now Ministry of Foreign Affairs. Taking a departure from the popular praises of Saigon as "the pearl of the Far East" and Hanoi as comparable to Paris, Herbelin (2016) instead shows how the architecture in Vietnam under French colonialism was the result of negotiations and political strategies between various authorities, between colonial and local authorities, between the native population and the French, as well as between the different technical and aesthetic solutions that were offered at that time. The book reveals, thus, there is no such thing as a proper colonial architecture but just a phenomenon of hybridization, of intertwined cultures that contribute to the colonial moment (Thu Hang, 2017). Along this vein, Truong (2012) analyzes the harmonization of Eastern and Western elements in the Indochine style in Vietnam to conclude on there being a strong imprint of traditional Vietnamese architecture. The Indochine style, the author argues, was after all born in Vietnam, and without doubt carries a large part of the native architectural elements, such as the use of wood and bamboo and the addition of balconies, verandahs, and internal corridors to accommodate the hot and humid tropical climate.

From a broader perspective, Hartingh, Craven-Smith-Milnes, and Tettoni (2007) review Vietnamese architecture from ancient to modern time and conclude that, although Vietnam's interior design has a touch of both Chinese and European cultures, the native design is quite diverse thanks to the varying characteristics of different Vietnamese localities. The book showcases the diversity of Vietnamese culture, as evidenced by the myriad temples, shrines, and pagodas across the country. Similarly, when looking at the traditions of Vietnamese architecture, Chu (2003) has documented a rich history of folkloristic architecture, from the way each household unit builds its house to the way a village and its folks contribute to the traditional architecture.

For the purpose of this study, based on extensive research on the topic, the team has summarized some notable ornamental characteristics in Table 1. These characteristics will form the basis of the analysis into the house façade in Hanoi.

\subsection{Hanoi Old Quarter and the house façade designs}

Upon its settlement in Hanoi in the late 19th century, the French soon began building its own streets and administrative offices. In 1883, the first governor issued a plan to turn some streets in the southeast of the Sword Lake (Ho Hoan Kiem)_equivalent with the streets of Le Phung Hieu, Ly Thai To, Le Thanh Ton, and Ngo Quyen today-fully into the style of French architecture. This area, dubbed by the Vietnamese as the

Table 1

A summary of the non-Vietnamese and Vietnamese use of materials and ornamental designs.

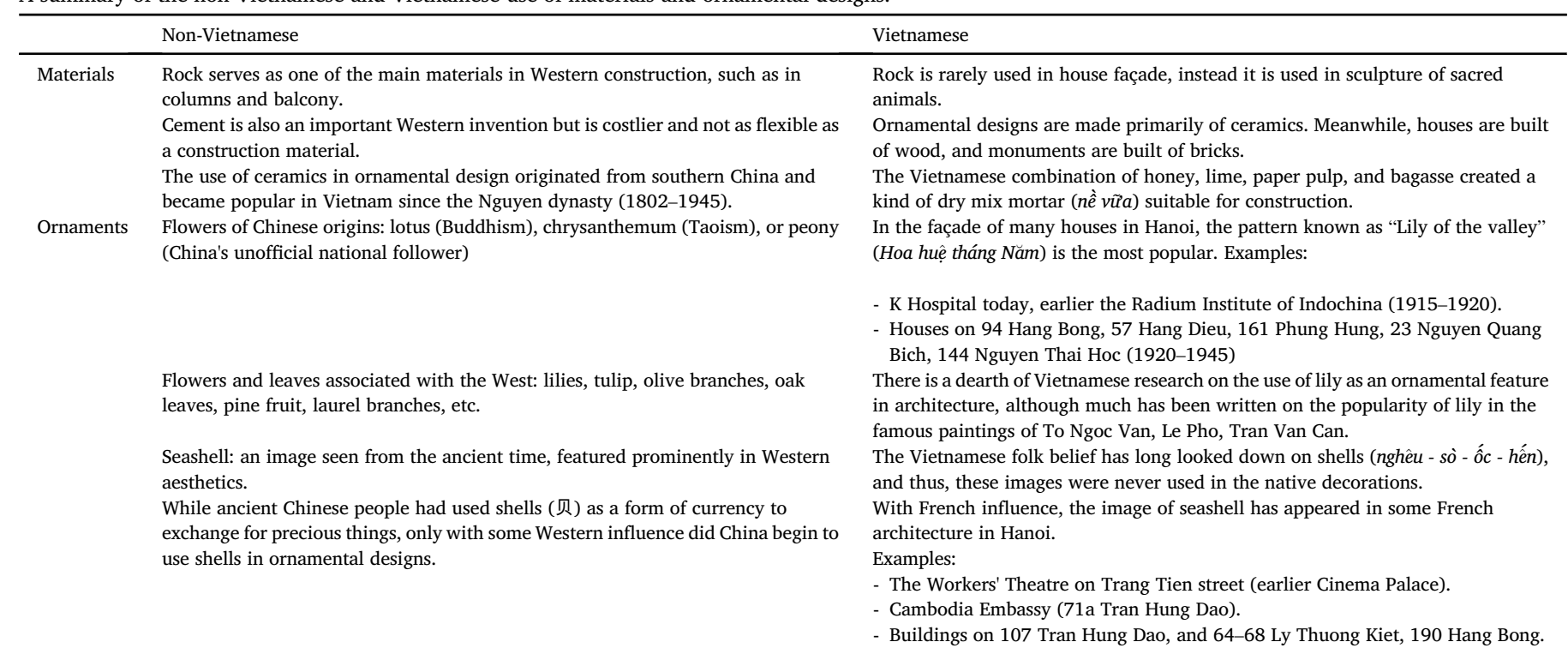

Traditional Chinese symbols: wine gourd, coin, four sacred flowers, four sacred mythical creatures (Taoism), words such as 寿 (longevity), 福 (happiness), 乐 (joy), 喜 (delight), 万 (ten thousand/great number). 
"Western quarter," stands in contrast with the old commercial area that is known as Hanoi's 36 streets located in the north of the Sword Lake (Dinh $\&$ Groves, 2006). A recent review of French urban planning in Hanoi pointed out that the French had built 157 streets in their style here between 1884 and 1945, of which 74 were strictly French with houses built in accordance with European style (Phan, Nguyen, Dao, Ta, \& Nguyen, 2017). Table 2 summarizes the three major periods of French influence over Hanoi architecture, based on the research by Tran Hau Yen The (2011).

Studies on the house façade in Hanoi Old Quarter have taken mostly a qualitative approach, delving into the ornamental designs and their historical and aesthetic values, as shown by Tran Hau Yen The (2011) and Phan Cam Thuong (2008). When looking at the house façade, one of the outstanding features is the combined use of Vietnamese national script (Chữ Quốc Ngữ), French, and Chinese (Hán) characters on advertisement billboards and entryways. The construction of many houses in Hanoi prior to 1945 shows the undeniable aesthetic appeal of having some Chinese texts on the façade. The display of written texts on the house façade, according to Tran Hau Yen The (2011), was a practice originated from Europe. Thanks to such inscriptions, one could observe the transforming aesthetics in Hanoi, from pure European style to an integrated East-West style.

The extensive literature review here lays an important foundation for this study. The aesthetic features to be examined are not only highly representative of their originating cultures, whether that be French or Chinese, but are also reflective of the relationship between the architectural theories and practical application. On this basis, the research team could categorize the most notable variables and structure the coding of such data in its Bayesian model. The following section will go into details the materials and methods of this research.

\section{Materials and methods}

\subsection{Materials}

This study started in 2007 when our artist, Bui Quang Khiem, started to take pictures of old houses in the Old Quarter of Hanoi. Each street in the 36 streets was originally home to a different trade, as reflected in the name of the street, such as Hang Bun for Rice Noodle Street or Hang Non for Conical Hat Street (Dinh \& Groves, 2006). As the craftsmen and traders brought their village culture and customs to Hanoi, the city saw an emergence of buildings characteristic of traditional Vietnamese village life, such as the communal house (đình), village pagoda (chùa), or village gate (cổng làng). Most of the houses in these streets were built during the French colonial period and they exhibit the typical characteristics of the two-storied tube houses built around the 20th century (Kien, 2008b). These houses are influenced by the architecture of the French houses and also reflect the wealth of their owners (Dinh \& Groves, 2006). From 2007 to 2018, Bui Quang Khiem took more than 500 pictures of the façades of the old houses around Hanoi. Fig. 2 shows two examples. The process of photo-taking is meticulous and time-consuming, given the lively economic life of the city and the country (Vuong, 2014). Many of the houses are covered in advertisement boards, as these houses are still used for daily activities, including small businesses. Hence, the photographer had to wait for the moment when the advertisements boards were put away. Many of the houses have been destroyed during the time and the pictures are the limited documents left of them. All of the pictures have been deposited openly online in the Open Science Framework (OSF)'s database and can be accessed at htt ps://osf.io/tfy6k/.

In September 2018, the research team started to select pictures that are suitable for the purpose of this study. This study has left out the

Table 2

An overview of the major historical events and characteristics of Hanoi architecture from 1860 to 1945, based on the research by Tran Hau Yen The (2011).

\begin{tabular}{|c|c|c|c|}
\hline $\begin{array}{l}\text { Time } \\
\text { period }\end{array}$ & Historical notes & Hanoi architecture & Notable examples \\
\hline 1860-1900 & $\begin{array}{l}\text { Only French army engineers could design and build houses, } \\
\text { thanks to their experience in building army bases in Algeria. } \\
\text { French troops officially took over Hanoi in } 1882 \text {. }\end{array}$ & $\begin{array}{l}\text { Most constructions were for military residence, jail/prison, } \\
\text { and church. } \\
\text { "Early colonial architecture": all architectural designs were } \\
\text { imported straight from France and Europe (Vietnam } \\
\text { Associations of Architects, 2003). }\end{array}$ & $\begin{array}{l}\text { - Vietnam Military History Museum } \\
\text { (earlier Hôtel du quartier général de } \\
\text { l'armée) (1877) } \\
\text { - Notre-Dame Cathedral Basilica of } \\
\text { Saigon (1877-1880) } \\
\text { - St. Joseph's Cathedral in Hanoi } \\
\text { (1883-1887) }\end{array}$ \\
\hline 1900-1920 & $\begin{array}{l}\text { The French began building administrative offices and houses } \\
\text { in the city. } \\
\text { Rapid urbanization gave rise to many urban centers and } \\
\text { resort towns from the north to the south. } \\
\text { The École Française D'Extrême-Orient (EFEO), French School } \\
\text { of Asian Studies, was founded in 1900, headquartered in } \\
\text { Hanoi. }\end{array}$ & $\begin{array}{l}\text { The dominant architecture is classical and neoclassical } \\
\text { style with a touch of different French regions. } \\
\text { Major administrative buildings were built in the grand } \\
\text { style, all designs were strictly symmetrical. }\end{array}$ & $\begin{array}{l}\text { - Hanoi Presidential Palace (earlier, } \\
\text { Residence of the Governor-General of } \\
\text { French Indochina) (1901-1907) } \\
\text { - Vietnam People's Supreme } \\
\text { Courthouse (earlier Courthouse) } \\
\text { (1906). } \\
\text { - Hanoi Opera House (earlier } \\
\text { Municipal Theatre) (1901-1911). }\end{array}$ \\
\hline \multirow[t]{2}{*}{ 1920-1945 } & $\begin{array}{l}\text { This period saw an integration of East-West values in the } \\
\text { local architecture, evidenced in the designs of the roof, } \\
\text { console system, and various decorations. } \\
\text { EFEO established a full Archeological Service, appointing } \\
\text { both European and local staff as faculty and assistants in the } \\
\text { preservation and restoration of historical monuments in } \\
\text { Indochina (Clementin-Ojha \& Manguin, 2007). }\end{array}$ & $\begin{array}{l}\text { The Indochine style (Ernest Herbrad, Charles Batteur): } \\
\text { more attention paid to the roof, ventilation, patios, doors } \\
\text { and windows; designs taking into account symbols } \\
\text { originated from Buddhism, Confucianism, and Taoism. } \\
\text { The Franco-Chinese style: more elaborate Chinese } \\
\text { decorations in Western buildings, more emphasis on the } \\
\text { chimney and the surface design of the roof. The windows } \\
\text { and doors of this style do not have as many shutters as those } \\
\text { in the Indochine style. }\end{array}$ & $\begin{array}{l}\text { - Vietnam Museum of History } \\
\text { - Vietnam Ministry of Foreign Affairs } \\
\text { - House No. } 18 \text { on Le Hong Phong } \\
\text { Street }\end{array}$ \\
\hline & & $\begin{array}{l}\text { The Art Décor style: became popular in 1930-1945; known } \\
\text { for its usage of geometric shapes, zigzag lines, bold color } \\
\text { and patterns, and metallic/iron materials. }\end{array}$ & $\begin{array}{l}\text { - State Bank of Vietnam Headquarters } \\
\text { (earlier Banque de l'Indochine) } \\
\text { - Villa No. } 9 \text { on Le Hong Phong Street. } \\
\text { - Trang Tien Palaza (earlier Godard } \\
\text { House) }\end{array}$ \\
\hline
\end{tabular}

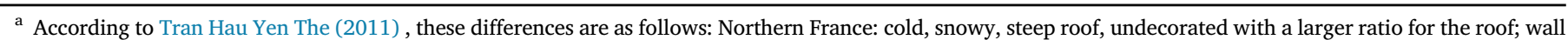

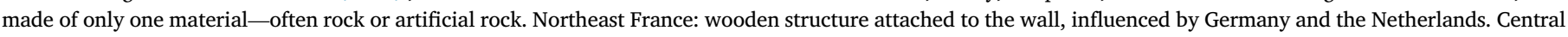

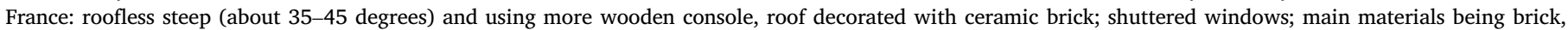

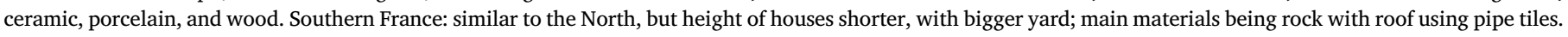




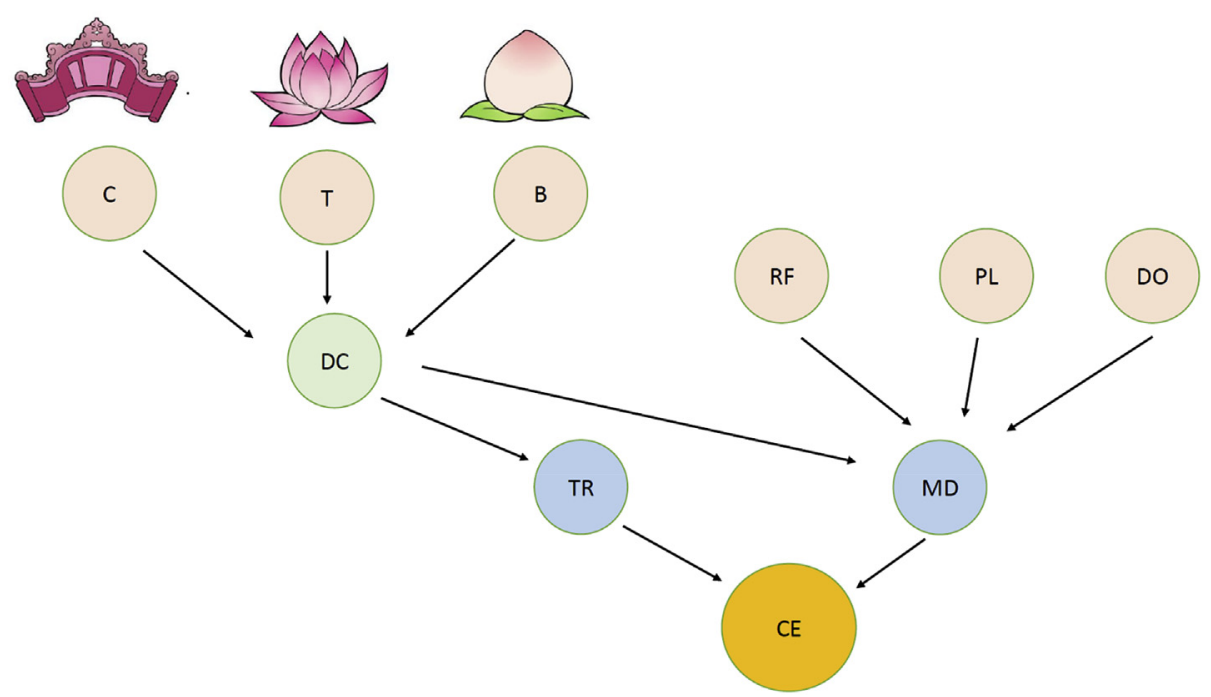

Fig. 3. The initial Bayesian network model. A directed acyclic graph which represents the probabilistic dependency among the variables.

It is important to note that in the beginning the DAG is an empty graph, meaning there is no probabilistic dependencies encoded in it. The next step is to add the relationships among the variables.

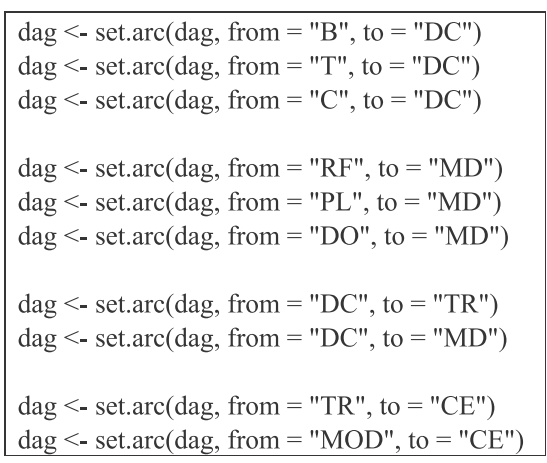

To test whether the DAG is correct, the plot function can be used. The result can be seen in Fig. 4.

$$
\begin{aligned}
\widehat{P R}(C E & \left.=C E_{-} E \mid M D=M D_{-} S\right)=\frac{\widehat{\operatorname{Pr}}\left(C E=" C E_{-} E^{\prime \prime}, M D=M D_{-} S\right)}{\widehat{\operatorname{Pr}}\left(M D=M D_{-} S\right)} \\
& =\frac{\text { number of observations for which } C E=C E_{-} E \text { and } M D=M D_{-} S}{\text { number of observations for which } M D=M D_{-} S}
\end{aligned}
$$

This is the classic frequentist and maximum likelihood estimates, for further discussions, see (Scutari \& Denis, 2014). In this study, in order to evaluate the structure of the Bayesian networks, the Bayesian Information Criterion (BIC) score (Equation (3)) is employed:

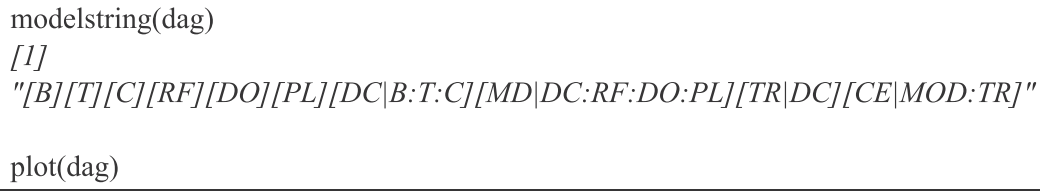

The formal definition of how the dependencies are encoded in the map into the probability space via conditional independence relationships is provided in Equation (1):

$\operatorname{Pr}(C, T, B, D C, R F, P L, D O, M D, T R, C E)$

$=\operatorname{Pr}(C) \operatorname{Pr}(T) \operatorname{Pr}(B) \operatorname{Pr}(R F) \operatorname{Pr}(P L) \operatorname{Pr}(D O) \operatorname{Pr}(D C \mid C, T, B) \operatorname{Pr}(M D \mid D C$, $R F, P L, D O) \operatorname{Pr}(\mathrm{TR} \mid \mathrm{DC}) \operatorname{Pr}(C E \mid M D, T R)$

The conditional probabilities in the local distributions can be estimated with the empirical frequencies in the datasets, for example, Equation (2) shows the conditional probabilities of a façade exhibits a strong presence of cultural evolution given it also gives off a strong feeling of modern:

$$
\begin{aligned}
B I C= & \log \widehat{\operatorname{Pr}}(C, T, B, D C, R F, P L, D O, M D, T R, C E)-\frac{d}{2} \log n \\
= & {\left[\log \widehat{\operatorname{Pr}}(C)-\frac{d_{C}}{2} \log n\right]+\left[\log \widehat{\operatorname{Pr}}(B)-\frac{d_{B}}{2} \log n\right]+[\log \widehat{\operatorname{Pr}}(T)} \\
& \left.-\frac{d_{T}}{2} \log n\right]+\left[\log \widehat{\operatorname{Pr}}(R F)-\frac{d_{R F}}{2} \log n\right]+\left[\log \widehat{\operatorname{Pr}}(P L)-\frac{d_{P L}}{2} \log n\right] \\
& +\left[\log \widehat{\operatorname{Pr}}(D O)-\frac{d_{D O}}{2} \log n\right]+\left[\log \widehat{\operatorname{Pr}}(D C \mid C, B, T)-\frac{d_{D C}}{2} \log n\right] \\
& +\left[\log \widehat{\operatorname{Pr}}(M D \mid D C, R F, P L, D O)-\frac{d_{M D}}{2} \log n\right]+[\log \widehat{\operatorname{Pr}}(T R \mid D C) \\
& \left.-\frac{d_{T D}}{2} \log n\right]+\left[\log \widehat{\operatorname{Pr}}(C E \mid M D, T R)-\frac{d_{M D}}{2} \log n\right]
\end{aligned}
$$




\section{Results}

4.1. Preliminary evaluation: a search for possible and meaningful causal models

First, the strength of probabilistic dependence corresponding to each arc in the initial model is tested using the arc.strength function in bnlearn package. The test returns non-significant results $(p>0.05)$ across the network. The following box details the codes and the results.

\begin{tabular}{|c|c|c|}
\hline \multicolumn{3}{|l|}{ strength $=$ arc.strength $($ dag, data $=$ data1, criterion $=" \times 2 ")$} \\
\hline \multicolumn{3}{|l|}{ from to strength } \\
\hline & & 1 BDC $9.763066 e-01$ \\
\hline & & $2 T D C 1.000000 e+00$ \\
\hline & & $3 C D C 9.999153 e-01$ \\
\hline & & 4 RFMD $1.000000 e+00$ \\
\hline & & $5 P L M D 1.000000 e+00$ \\
\hline & & $6 D O M D 1.000000 e+00$ \\
\hline & & 7 DC TR 3.093218e-08 \\
\hline & & $8 D C M D 1.000000 e+00$ \\
\hline & & $9 \quad T R$ CE $7.989842 e-01$ \\
\hline & & 10 MD CE 9.174464e-01 \\
\hline
\end{tabular}

With the initial Bayesian network model whose Bayesian Information criterion (BIC) score equals -979.0649 and Bayesian Dirichlet equivalent uniform (BDen) score equals -552.611 , not showing any significance, 200 random DAGs are generated using machine algorithms for a further investigation of the relationship among the variables. Table 3 provides 21 DAGs that satisfy the technical requirements. The initial criteria for generating the DAGs are: (i) there are connections to $\mathrm{CE}$; (ii) there is no connection from CE; and (iii) the minimum number of connections is at least five.

The following box shows the codes to compute the scores for the generated networks and to select the ones with the best BIC scores.

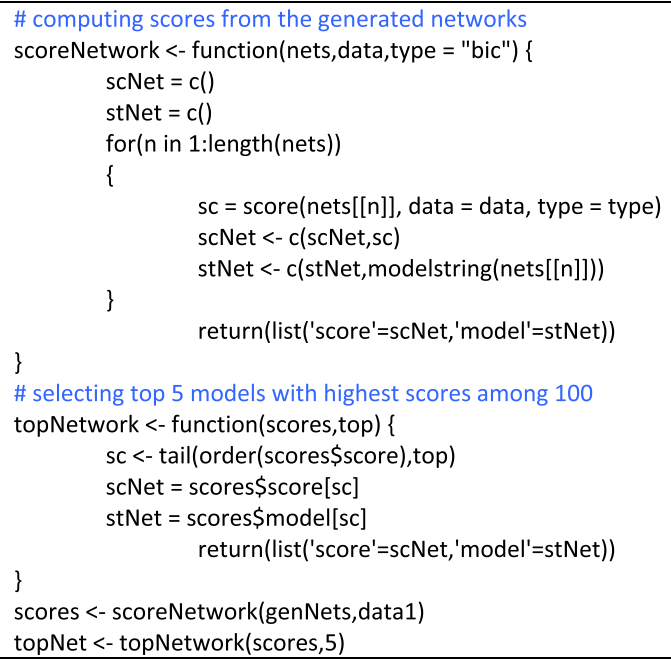

The top five models were chosen on the basis that they have higher BIC network scores and they are M13, M7, M4, M8, and M5.

\subsection{Inference from the top four models}

It is notable that all models start with the dependency of decoration (DC) on Buddhism-inspired decorative patterns (B). In other words, the value DC takes (Chinese, French or Hybrid) is probabilistically dependent on the value of B (none, weak or strong). Second, in all the models, there are some forms of interactions between the decoration (DC) variable and Cultural Evolution (CE) variable. For example, in Table 4, for M13 and

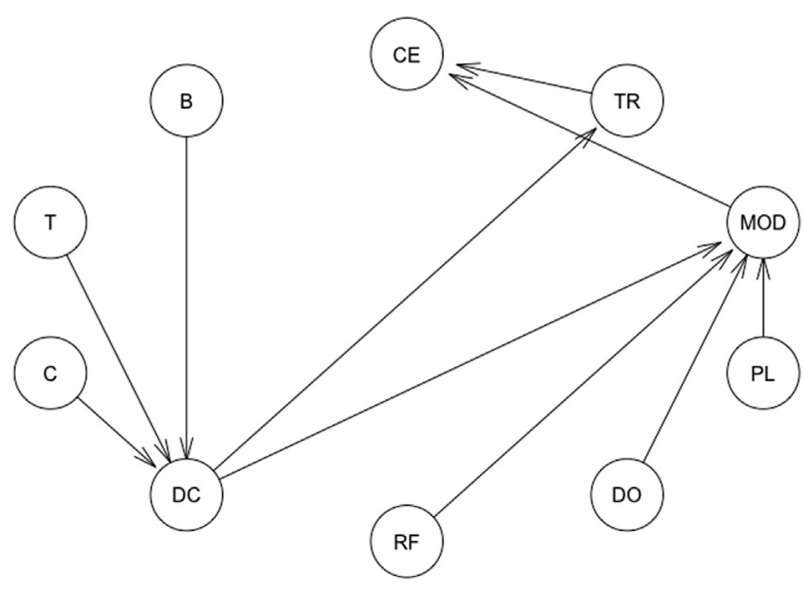

Fig. 4. The DAG created using the bnlearn package. This directed acyclic graph is identical to the one presented in Fig. 3.

M7, CE is directly dependent on DC; in M4 and M8, CE is indirectly dependent on DC through the roof design (RF). All four models are statistically significant under the frequentist approach, however, as they can be categorized in the two patterns above, the next section will focus on the best model for each pattern: M4 and M13.

In model M13, as shown in Fig. 5, when Buddhism-inspired decorative patterns are strong (B_S), the probability of the Decoration variable (DC) takes on the value of hybrid (HY) and (CN) increases compared with when B equals none (B_N). When there is a weak presence of Buddhisminspired decorative patterns/symbols, DC most likely takes on the value hybrid (HY) (90\%). For the variable Cultural evolution (CE), when the decoration of a façade is hybrid, the probability of the cultural evolution process is happening ( $\mathrm{CE}=\mathrm{CE} \_\mathrm{E}$ ) is highest $(90 \%)$. When the decoration is judged to be Chinese, the probability of CE just started equals roughly $60 \%$. When the decoration is judged to be French, the probability of CE process has finished equals around 55\%.

In Fig. 6, concerning the M4 model, the judgment on the cultural evolution process (CE) is dependent on whether the roof (RF) is Chinese, French or Hybrid. When the roof is Chinese style, the probability of the CE process just started is the highest, $60 \%$. When the roof is hybrid, the probability of the CE process is happening is more than $80 \%$.

\subsection{Robustness verification with Hamiltonian MCMC pondering for Bayesian networks: JAGS and Stan}

In this section, the four best models are verified using the Hamiltonian MCMC method. One of the strengths of the Bayesian statistics approach is that it can generate technical figures for verification (Kruschke, 2015; McElreath, 2016). Using both the JAGs and Stan, this study diagnoses the robustness of the M4 and M13 Bayesian networks. The estimation has in total 20,000 iterations divided into 4 Markov chains. The file that contains all of the results (including the results for model M8, M7, and M5) is deposited in OSF's "Statistical Investigations" folder, "Files" sub-folder [URL: https://osf.io/tfy6k/].

The posterior distributions of all coefficients for model M4, as shown in Fig. 6, all satisfy the standard distribution. In Fig. 7, we presented an example of testing the validity of the coefficients $\beta_{\{C E \cdot R F\}}$ in M4, where $\mathrm{CE}$ is dependent on RF probabilistically. Here, one can see the chains fluctuate around 0.4 and has a good-mix (Fig. 7, top left). For the autocorrelation function, the four chains converge very quickly after lag 3 and the effective sample size (ESS) is nearly 66,700, indicating computational efficiency. Shrinking factor of computed mean values converged to 1.0 quite fast, while the Monte Carlo standard error (MCSE) is less than $0.05 \%$ (see Fig. 8).

Similar to M4, the model M13 is also verified using the MCMC method. Fig. 9 shows all posterior distributions of the coefficients of this 
Table 3

Twenty-one DAGs with the best BIC scores are presented. Note that all of the scores are better than the initial model.

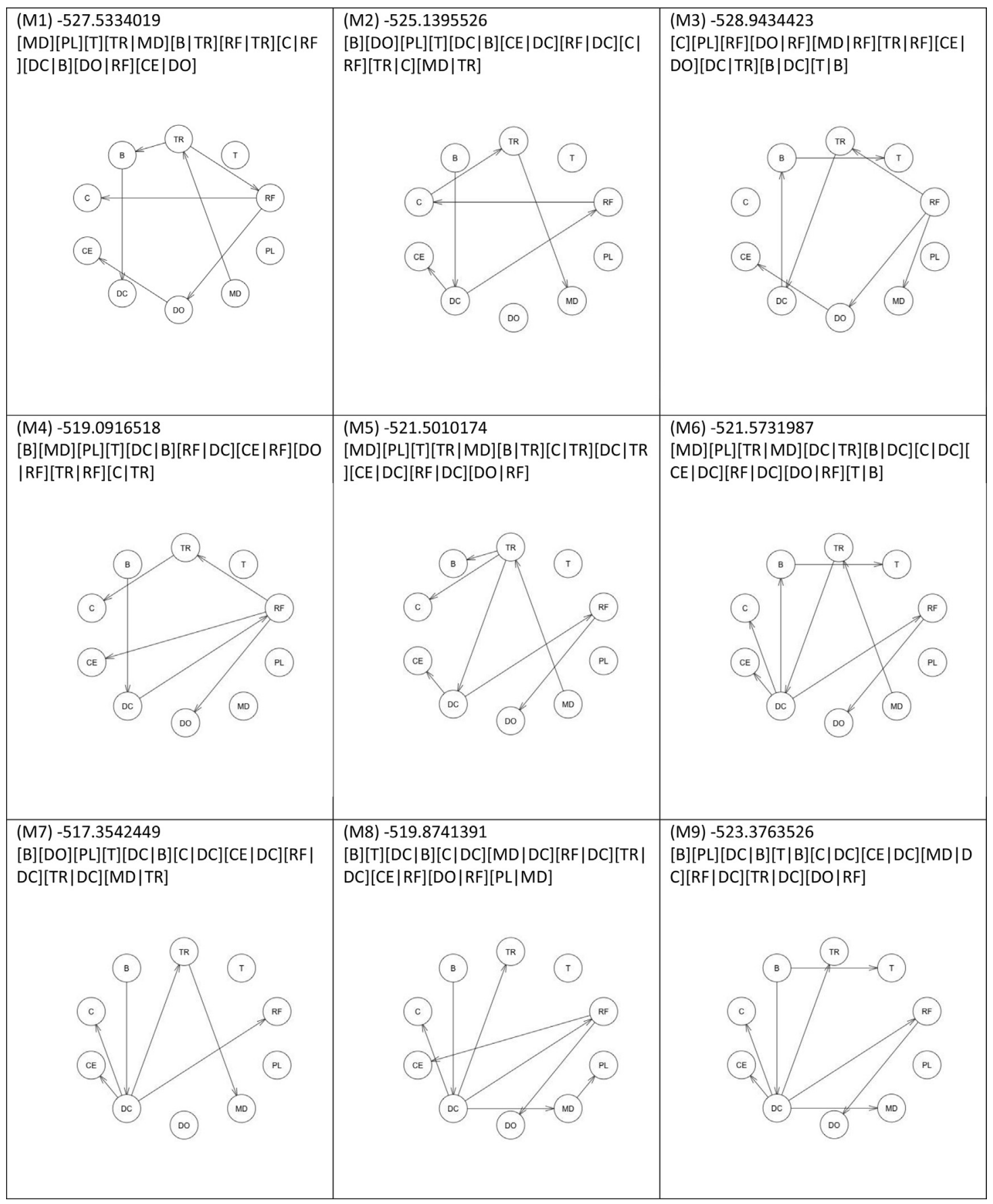




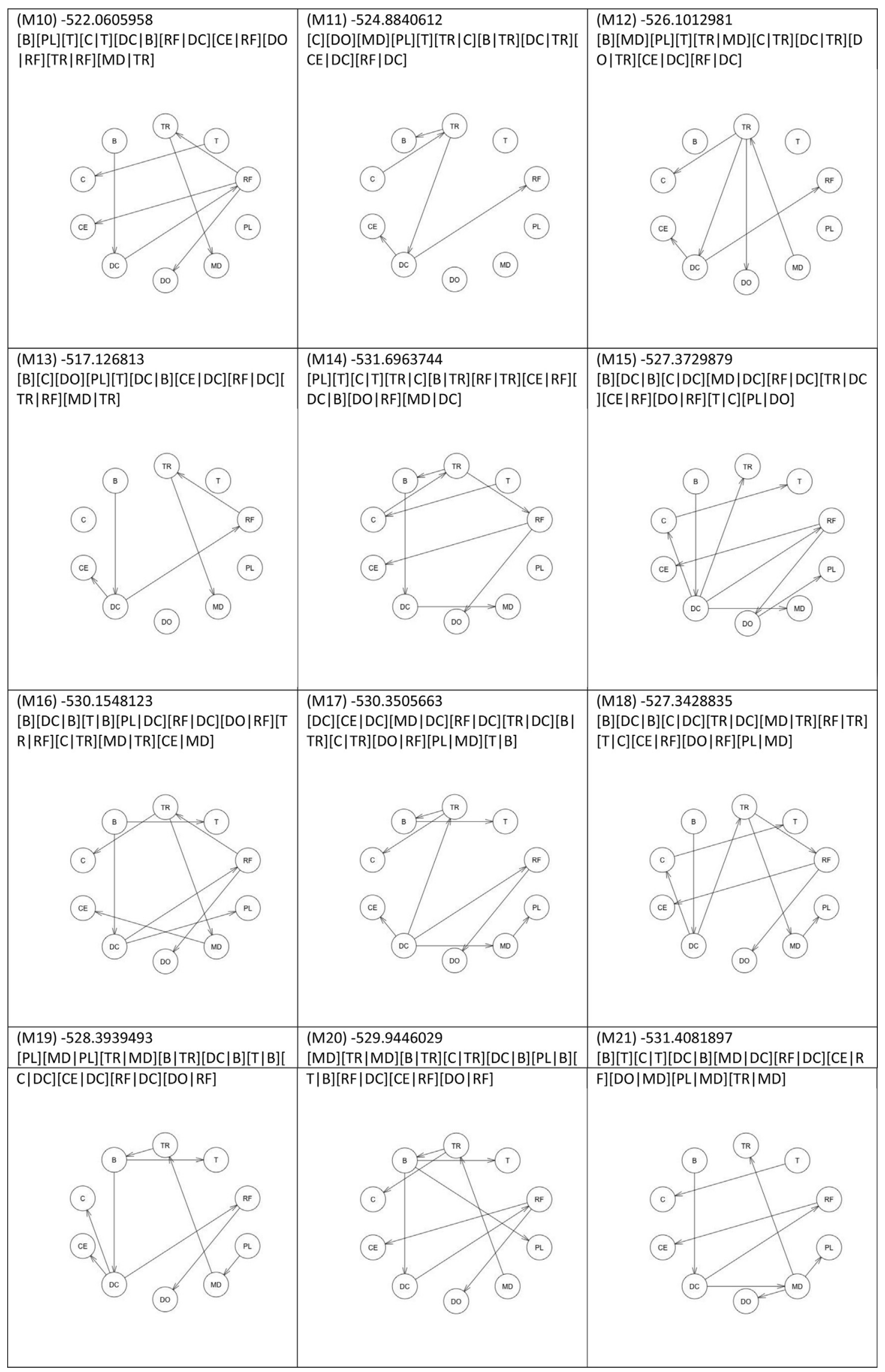


Table 4

Four models with the best network scores are presented.

\begin{tabular}{|c|c|c|c|c|}
\hline Score & $\begin{array}{l}\text { Arc } \\
\text { Strength } \\
(\mathrm{x} 2)\end{array}$ & $\begin{array}{l}\text { Arc } \\
\text { Strength } \\
\text { (mi) }\end{array}$ & ci.test (mi) & ci.test (x2) \\
\hline $\begin{array}{l}\text { (M13) } \\
-517.13\end{array}$ & $\begin{array}{l}\text { B- }>\text { DC } \\
4.51 \mathrm{E}-06 \\
\text { DC- }>\text { CE } \\
2.98 \mathrm{E}-06 \\
\text { DC- }>\text { RF } \\
1.35 \mathrm{E}-13 \\
\text { RF- }>\text { TR } \\
8.59 \mathrm{E}-07 \\
\text { TR- }>\text { MD } \\
1.66 \mathrm{E}-06\end{array}$ & $\begin{array}{l}\text { B- }>\text { DC } \\
8.86 \mathrm{E}-06 \\
\text { DC- }>\text { CE } \\
6.83 \mathrm{E}-04 \\
\text { DC- }>\text { RF } \\
1.01 \mathrm{E}-06 \\
\text { RF- }>\text { TR } \\
1.55 \mathrm{E}-05 \\
\text { TR- }>\text { MD } \\
1.41 \mathrm{E}-04\end{array}$ & $\begin{array}{l}\text { ci.test(“CE", } \\
\text { "DC",c("B"), } \\
\text { test }=\text { "mi", } \\
\text { data }=\text { data1) } \\
\text { data: } C E \sim D C \mid B \\
m i=21.477, \\
d f=12, p- \\
\text { value }=0.04381\end{array}$ & $\begin{array}{l}\text { ci.test("CE", } \\
\text { "DC",c("B"), } \\
\text { test }=\text { "x2", } \\
\text { data }=\text { data1) } \\
\text { data: } C E \sim D C \mid B \\
x 2=19.145, \\
d f=12, p- \\
\text { value }=0.08509\end{array}$ \\
\hline $\begin{array}{l}\text { (M7) } \\
-517.35\end{array}$ & $\begin{array}{l}\text { B- }>\text { DC } \\
4.51 \mathrm{E}-06 \\
\text { DC- }>\text { C } \\
8.69 \mathrm{E}-03 \\
\text { DC- > CE } \\
2.98 \mathrm{E}-06 \\
\text { DC- > RF } \\
1.35 \mathrm{E}-13 \\
\text { DC- > TR } \\
3.09 \mathrm{E}-08 \\
\text { TR- }>\text { MD } \\
1.66 \mathrm{E}-06\end{array}$ & $\begin{array}{l}\text { B- }>\text { DC } \\
8.86 \mathrm{E}-06 \\
\text { DC- }>\text { C } \\
3.01 \mathrm{E}-03 \\
\text { DC- > CE } \\
6.83 \mathrm{E}-04 \\
\text { DC- > RF } \\
1.01 \mathrm{E}-06 \\
\text { DC- }>\text { TR } \\
1.01 \mathrm{E}-05 \\
\text { TR- }>\text { MD } \\
1.41 \mathrm{E}-04\end{array}$ & $\begin{array}{l}\text { ci.test("CE", } \\
\text { "DC",c("B"), } \\
\text { test }=\text { "mi", } \\
\text { data }=\text { data1) } \\
\text { data: } C E \sim D C \mid B \\
m i=21.477, \\
d f=12, p- \\
\text { value }=0.04381\end{array}$ & $\begin{array}{l}\text { ci.test("CE", } \\
\text { "DC",c("B"), } \\
\text { test }=\text { "x2", } \\
\text { data }=\text { data1) } \\
\text { data: } C E \sim D C \mid B \\
x 2=19.145, \\
\text { df }=12, p- \\
\text { value }=0.08509\end{array}$ \\
\hline $\begin{array}{l}\text { (M4) } \\
-519.09\end{array}$ & $\begin{array}{l}\text { B- }>\text { DC } \\
4.51 \mathrm{E}-06 \\
\text { DC- }>\text { RF } \\
1.35 \mathrm{E}-13 \\
\text { RF- > CE } \\
3.37 \mathrm{E}-07 \\
\text { RF- > DO } \\
3.92 \mathrm{E}-09 \\
\text { RF- }>\text { TR } \\
8.59 \mathrm{E}-07 \\
\text { TR- >C } \\
2.17 \mathrm{E}-03\end{array}$ & $\begin{array}{l}\text { B- }>\text { DC } \\
8.86 \mathrm{E}-06 \\
\text { DC- }>\text { RF } \\
1.01 \mathrm{E}-06 \\
\text { RF- > CE } \\
3.50 \mathrm{E}-04 \\
\text { RF- }>\text { DO } \\
8.80 \mathrm{E}-04 \\
\text { RF- }>\text { TR } \\
1.55 \mathrm{E}-05 \\
\text { TR- }>\text { C } \\
3.03 \mathrm{E}-03\end{array}$ & $\begin{array}{l}\text { data: } C E \sim R F \mid D C \\
m i=15.966 \\
d f=12, p- \\
\text { value }=0.1928\end{array}$ & $\begin{array}{l}\text { data: } C E \sim R F \mid D C \\
x 2=25.327 \\
d f=12, p- \\
\text { value }=0.01335\end{array}$ \\
\hline $\begin{array}{l}\text { (M8) } \\
-519.87\end{array}$ & $\begin{array}{l}\text { B- > DC } \\
4.51 \mathrm{E}-06 \\
\text { DC- }>\text { C } \\
8.69 \mathrm{E}-03 \\
\text { DC- }>\text { MD } \\
2.16 \mathrm{E}-09 \\
\text { DC- }>\text { RF } \\
1.35 \mathrm{E}-13 \\
\text { DC- }>\text { TR } \\
3.09 \mathrm{E}-08 \\
\text { RF- > CE } \\
3.37 \mathrm{E}-07 \\
\text { RF- > DO } \\
3.92 \mathrm{E}-09 \\
\text { MD- > PL } \\
2.37 \mathrm{E}-16\end{array}$ & $\begin{array}{l}\text { B- > DC } \\
8.86 \mathrm{E}-06 \\
\text { DC- > C } \\
8.69 \mathrm{E}-03 \\
\text { DC- > MD } \\
7.31 \mathrm{E}-04 \\
\text { DC- }>\text { RF } \\
1.01 \mathrm{E}-06 \\
\text { DC- }>\text { TR } \\
1.01 \mathrm{E}-05 \\
\text { RF- > CE } \\
3.50 \mathrm{E}-04 \\
\text { RF- > DO } \\
8.80 \mathrm{E}-04 \\
\text { MD- > PL } \\
1.08 \mathrm{E}-02\end{array}$ & $\begin{array}{l}\text { data: } C E \sim R F \mid D C \\
m i=15.966 \\
d f=12, p- \\
\text { value }=0.1928\end{array}$ & $\begin{array}{l}\text { data: } C E \sim R F \mid D C \\
x 2=25.327 \\
d f=12, p- \\
\text { value }=0.01335\end{array}$ \\
\hline
\end{tabular}

model, all of them satisfy the technical requirement. Fig. 10 shows the Hamiltonian MCMC diagnostics for the two coefficients of the cultural evolution variables in M13. All of the technical measurements indicate a convergence of the posteriors.

\section{Discussion}

\subsection{Technical implications}

The current research first and foremost carries a huge implication for the application of Bayesian analysis in the study of culture and social anthropology. Its methodology diverges from the mainly qualitative approach of the literature on Franco-Chinese influence in Southeast Asian architecture as well as in Vietnam (Dinh \& Groves, 2006; Hartingh et al., 2007; Herbelin, 2016; Le, 2013; Nguyen, 2014; Nguyen, 2016; Phan et al., 2017; Tran Hau Yen The, 2011; Tran \& Nguyen, 2012; Truong, 2012; Vietnam Associations of Architects, 2003; Vongvilay et al., 2015; Walker, 2011). It also supplements the computational movement toward Bayesian-based research on cultural evolution in Asia (Higham \& Higham, 2009; Kumar et al., 2008; Lee \& Hasegawa, 2011; Long \& Taylor, 2015; Thouzeau, Mennecier, Verdu, \& Austerlitz, 2017).

Through the Bayesian networks analysis, the study shows that, despite a small volume of data and coding of highly representative variables, it is nonetheless plausible to find the impacts of certain cultural elements on the aesthetics, architecture decisions of people at that time. What should be emphasized here is the subjective probability characterization in judging the architectural feeling of the house façade. This is in fact a position underlying almost all Bayesian work, where prior information is often subjective due to the inclusion of the researchers' experience, intuition, theoretical ideas, or personal observations (Gill, 2002). This process in itself implies a limited number of observations, but in no way undermines the statistical analysis that follows. By giving equal value to every input in judging the Franco-Chinese or hybrid modern feeling of a house façade, the study takes the mean or mode in Bayesian posterior distribution, ruling out the possibility of any "expert opinion" being more valuable. This approach is in line with the probabilistic interpretation of regularization in Bayesian statistics, and thus, shows its rich potential in social sciences studies as a whole (Kruschke, 2015; La \& Vuong, 2019; McElreath, 2016; Vuong et al., 2018b; Vuong \& La, 2019).

It is important to note here that, although the findings do not confirm the presumed model (Fig. 2), the in-depth technical analysis confirms the plausibility of judging the aesthetics, architecture, and designs of the house façade in Hanoi to find traces of cultural evolution in the early 20th century in Vietnam. By highlighting ornamental features that are highly representative of French and Chinese cultures as well as their hybridity, the study was able to construct an efficient Bayesian model that draws out the association and correlation among different variables.

\subsection{Social anthropology implications}

\subsubsection{The flow of cultural evolution}

Among the notable findings, the study confirms that there is indeed a strong cultural evolutionary signal in the architecture of the house fronts in Hanoi. In the two models with the highest BIC scores, there is a high probability of the $\mathrm{CE}$ variable taking the value 'strong representation of cultural evolution' (CE_E). This result is best understood once the old houses are situated in the right historical context. Vietnamese society in the early 20th century was at a crossroad of ambiguity, both in terms of political and cultural identities, due to the intense competition among the deep-seated roots of the Three Religions (Confucianism, Buddhism, and Taoism) as well as Chinese and French influence. Phan et al. (2017) noted that, although $80 \%$ of the inhabitants in the Western quarter in Hanoi were Vietnamese, ${ }^{1}$ since the first half of the twentieth century, there had always been a large number of foreign inhabitants, such as Chinese, Indian, and the biggest group of all - French (Tran Hau Yen The, 2011). Given that the house, especially its façade, represents the face of the family and its biggest asset, its architecture inevitably reflects the cultural influences of the time. Against this background, it becomes clear why houses built during this period exemplify the Vietnamese souls that were torn between the traditional Confucian path and the liberal French style. On the evolving architecture in Vietnam, Herbelin (2016) also pointed out that, besides the urbanization, the cityscape in the early 20th century had changed dramatically because the French eradicated many laws on limiting household expenditure that were issued by the Nguyen dynasty earlier. As the people got to freely build two-storied houses and decorate them to their liking, these neoclassical designs were the results of influence from both France and China, where the East-West architectural fusion also took off strongly at the time (Herbelin, 2016).

\footnotetext{
1 In 1948, there were 150,000 Hanoi inhabitants. The figure rose to 300,000 in 1951 and to 643,576 in 1960 Nguyen V U (2016) Hà Nội nửa đầu thế kỷ XX [Hanoi in the first half of the XX century]. Third edition edn. Hanoi: Nha xuat ban Ha Noi.
} 


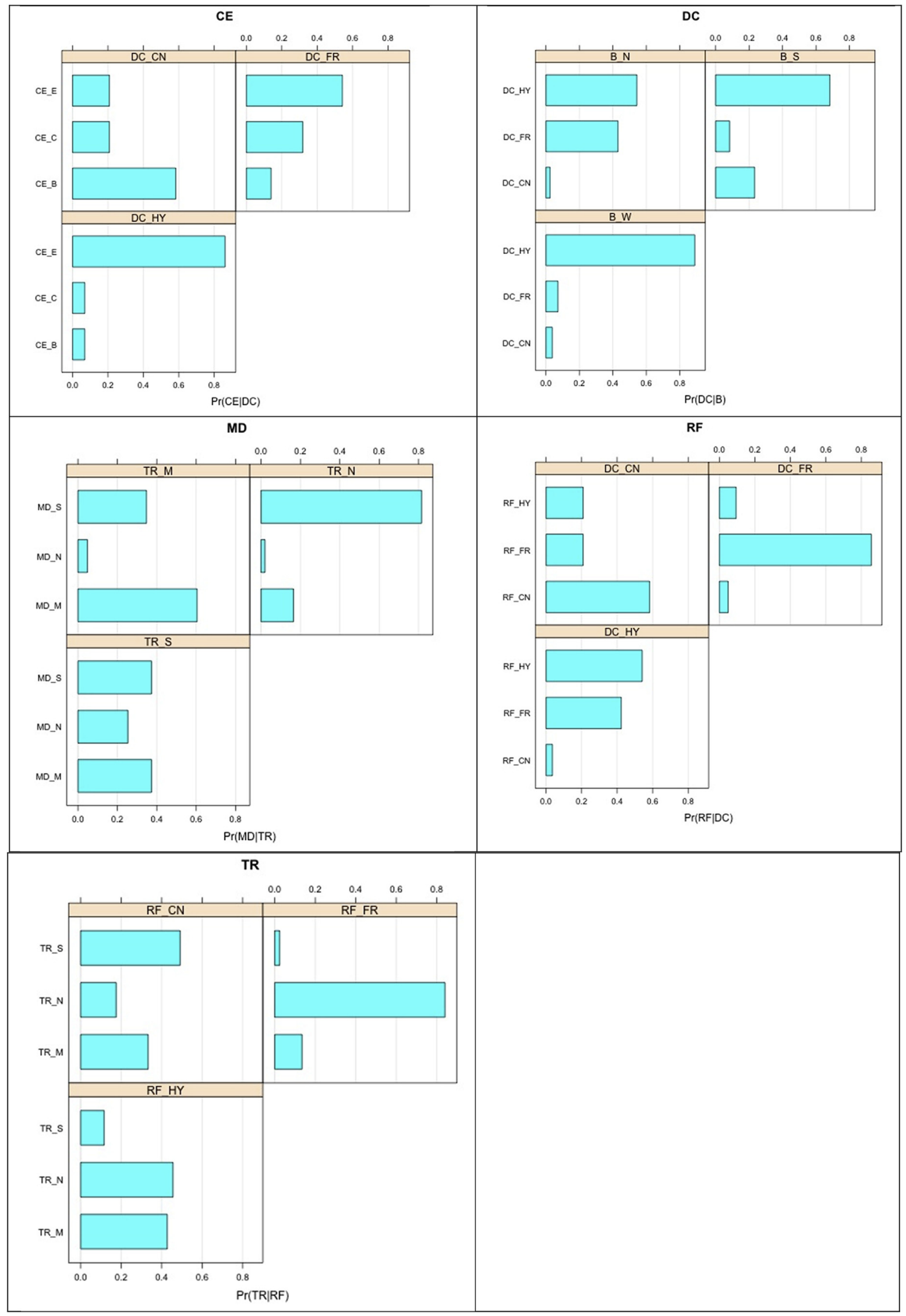

Fig. 5. Probability distribution of the categorical variables in model M13 given different evidences. 


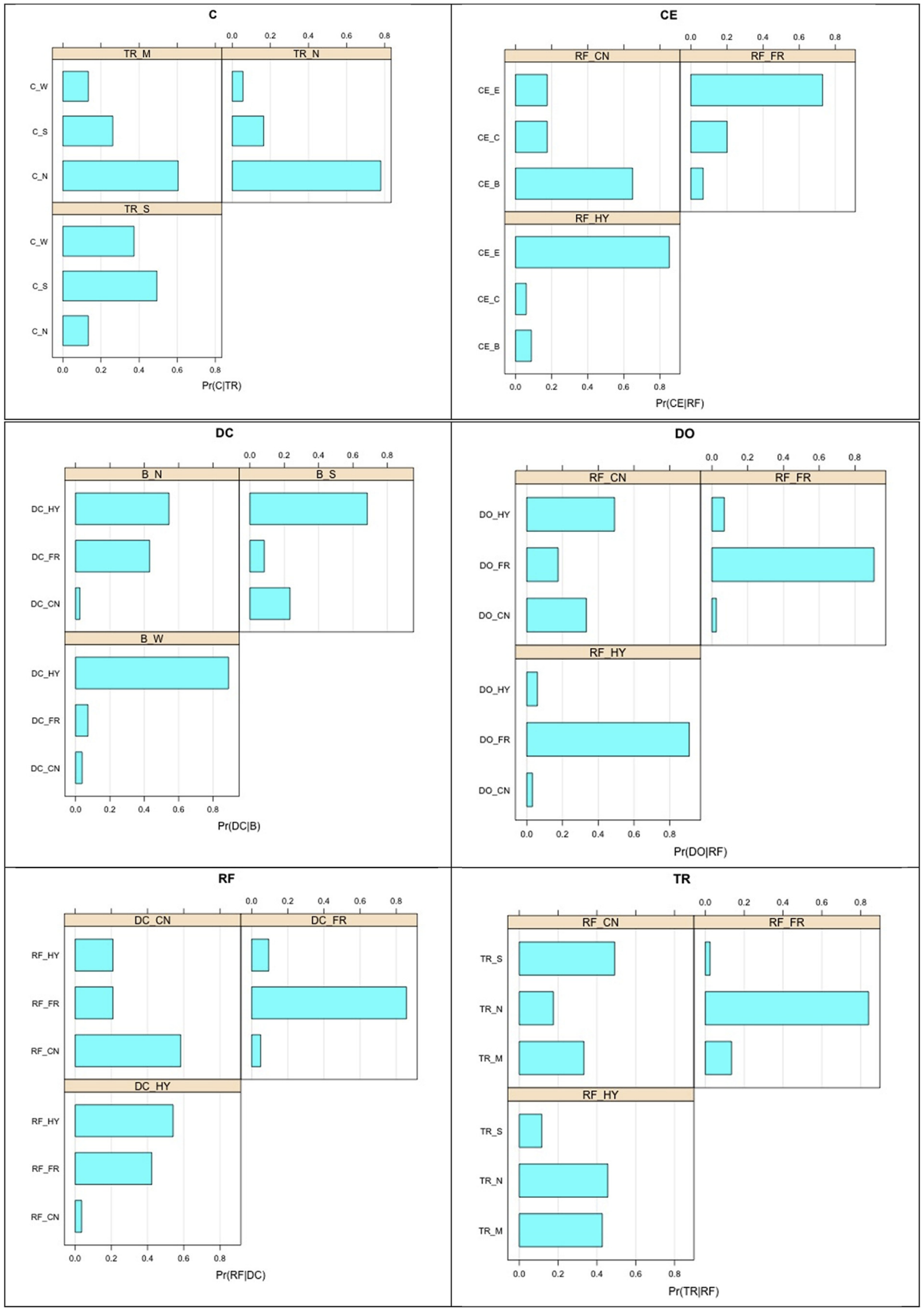

Fig. 6. Probability distribution of the categorical variables in model M4 given different evidences. 

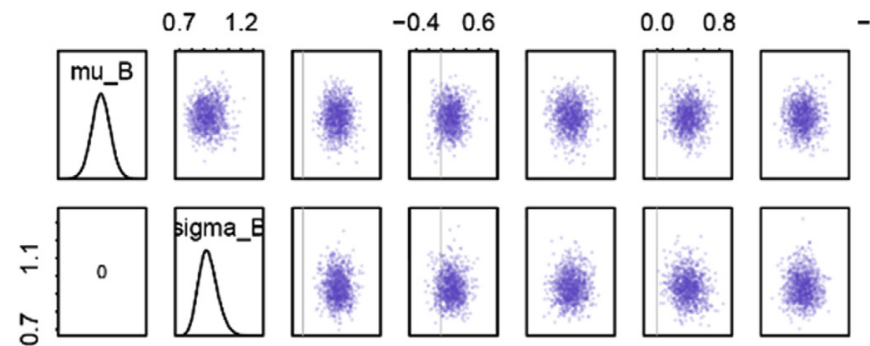

$\begin{array}{ll}-0.1 & 0.4\end{array}$

$\begin{array}{ll}-0.3 & 0.1\end{array}$

$\begin{array}{ll}-0.8 & 0.2\end{array}$
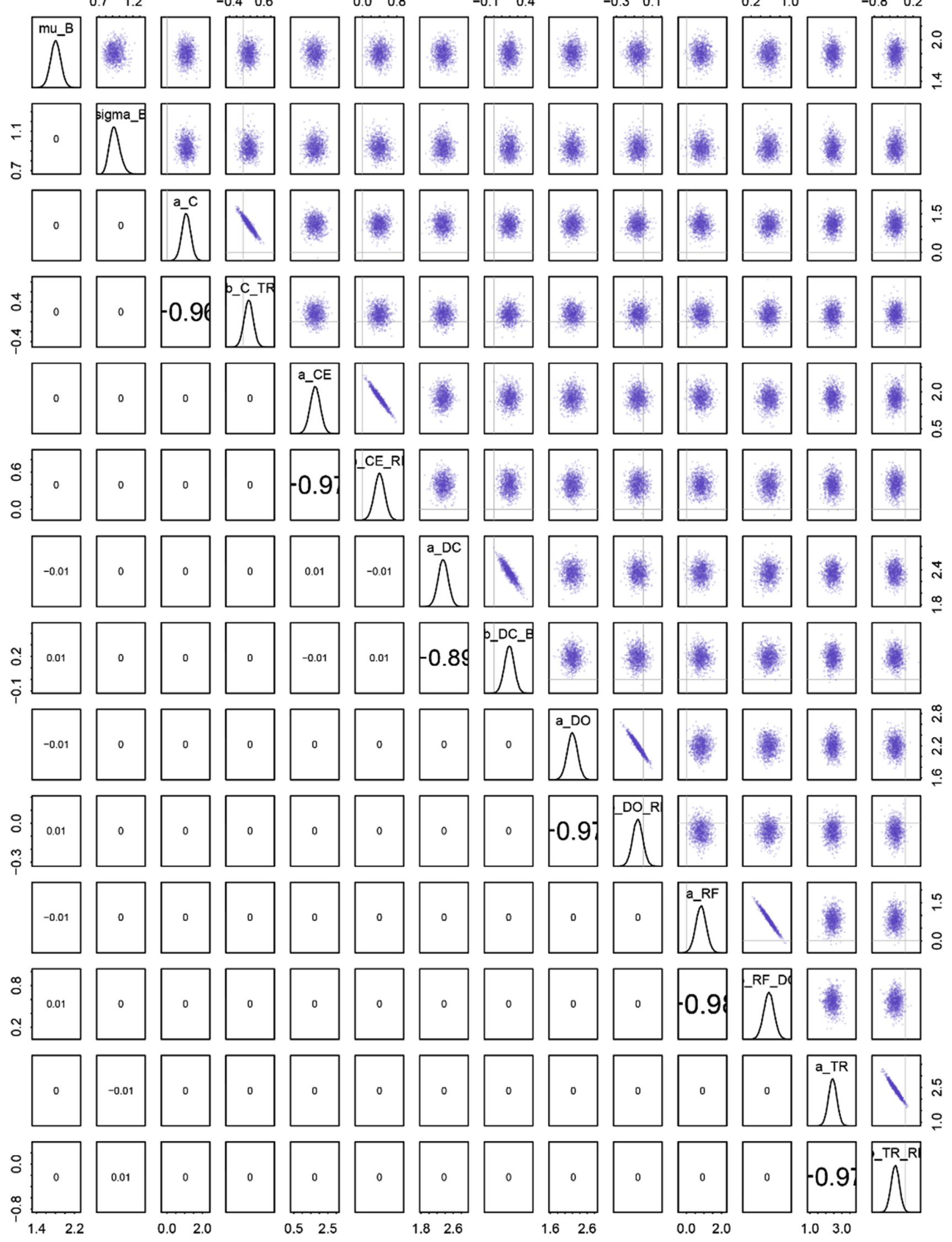

Fig. 7. M4's coefficients' posterior distribution. 


\section{b_CE_RF}
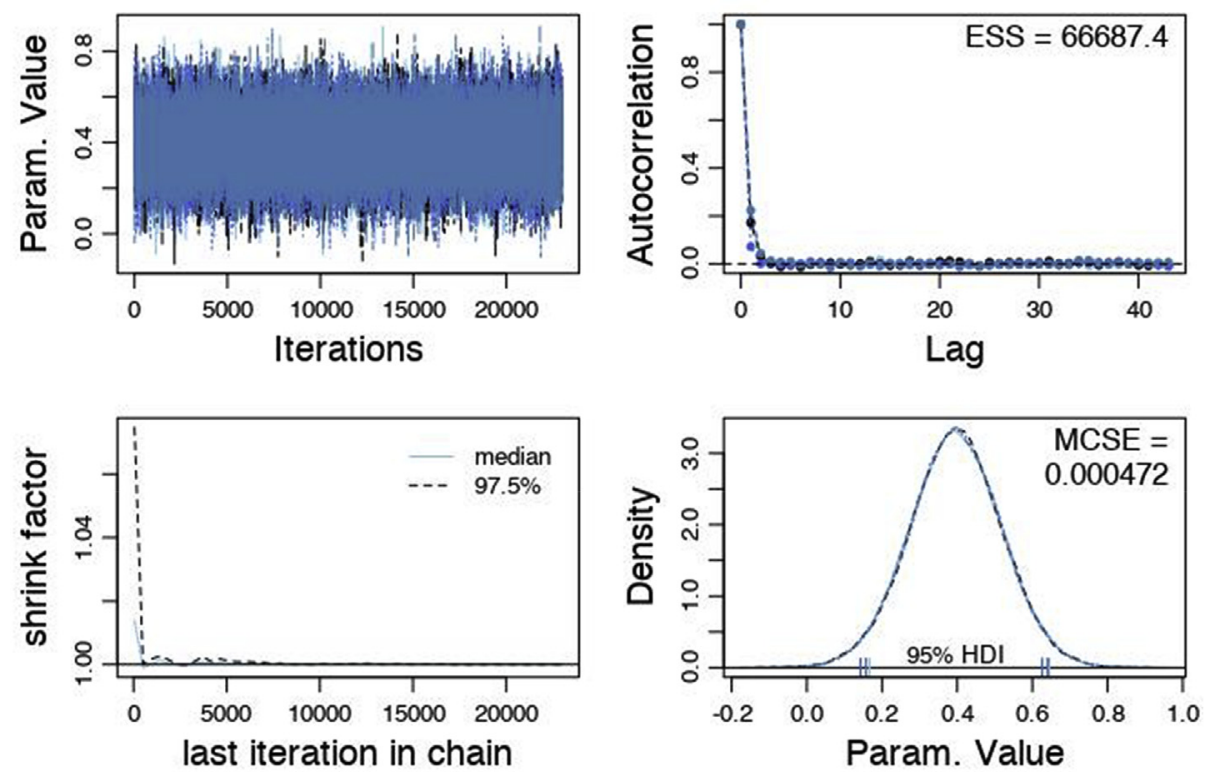

Fig. 8. Hamiltonian MCMC technical validations for $\beta_{\{C E \cdot R F\}}$ in model M4 using Stan codes.

It is perhaps the longing for this past that makes Bui Xuan Phai's oil paintings about Hanoi Old Quarter appealing. The artist himself is a product of the politics and culture of the time, having been born into a Confucian family but educated at the École Supérieure des Beaux-Arts de l'Indochine (Indochina College of Fine Arts), the former name of the Vietnam University of Fine Arts (André-Pallois, 2016). As the war against the French broke out, he then joined the cultural front to produce propaganda poster art in 1945; he relocated to the countryside in 1958 for manual labor with the peasants under a Party policy, but by 1966 had decided to pursue artistic expressionism free from any political agency (Bui \& Tran, 1998; Naziree, 2006). His experiences translated into his paintings of Hanoi-the resilience of the time shown in the houses that may appear wobbly but have stood there for decades. In his paintings, the streets of Hanoi came alive in simple brushstrokes of bold borders and mundane gray and white colors. The cityscape in Phai's paintings, often understood in three periods of 1960-1970, 1970-1980, and 1980-1988, appeared in a familiar and simple form with subtle signs of evolution: the two-storied houses, attached to one another like stacking matchboxes with the same dark brown brick roofs, were old and undecorated, their doors perpetually shut; then as the 1970s-1980s came, the houses' shuttered windows were painted in more details instead of in one black brushstroke and the first sign of modernity emerged in the form of a lamppost. In other words, Phai had captured the angst, poverty, and aesthetics of wartime Hanoi, all the while exemplifying the resilience and somewhat helplessness of Vietnamese people then when facing intense foreign cultural influences.

The findings here also highlight one aspect of cultural evolution - its direction. If the architecture in Hanoi is still evolving, presumably toward modernity, one question arises: will the Chinese influence retain as China, a close neighbor to the north of Vietnam, rises in the world? The current research implies that China cannot possibly reverse the flow of cultural evolution in Vietnam, in this case, its architecture. Yet, one fact that will not change regardless of the geopolitics is the inexplicable Vietnamese affection for hanging Chinese characters on their house façade or in their home. Vietnamese people lining up to buy calligraphy during the Lunar New Year (Têt) is not just a scene representing the lively modern economic life but also a behavior that signifies the nostalgia and the embrace of tradition (Pham, 2018).

\subsubsection{The strong signals of Buddhist decorations on the house façade}

Regarding the elements that most affect the Vietnamese perception on cultural evolution of Hanoi architecture in the early 20th century, the Bayesian networks investigation into Hanoi architecture indicates a strong influence of Buddhism over the decorations of the house façade. In the top 5 networks with the best BIC scores and small $p$-values, the variable DC always has a direct probabilistic dependency on the variable B. Given the predominance of Confucianism in Vietnamese culture (Vuong, 2016; Vuong, Vuong, Nguyen, \& Ho, 2019; Vuong \& Tran, 2009), this result is quite interesting. Two possible explanations could account for this finding. First, the lack of Confucian presence is attributable to the end of Hán script in academic and official settings in 1919 and the elevation to national status of Chữ Quốc Ngữ in Vietnam in 1945 (Chiung, 2007; Trinh, 2000). Second, it is possible that some of the French architects who were involved in the planning and building of Hanoi at the time had been influenced by Buddhism during their work with the École Française D'Extrême-Orient (EFEO), the French School of Asian Studies founded in 1900. As Clementin-Ojha and Manguin (2007) noted, in 1920, the EFEO established a full Archeological Service and Charles Batteur was tasked with the restoration of Vietnamese antiquities. In 1922, Charles Batteur helped restore the Pagoda of the Single Pillar (Chùa Một Cột) in Hanoi and numerous other pagodas that were damaged by a typhoon in 1929 (Clementin-Ojha \& Manguin, 2007). The architects' involvement in preserving and restoring the Buddhist pagodas may help explain the somewhat prominent feature of Buddhist decorations in the house façade in Hanoi.

The strong signal of Buddhism on the house façade in the 20th century is also an interesting finding given that Buddhist pagodas and Buddhist office buildings in North Vietnam were either destroyed or confiscated during the 1950s and 1960s, known as the "cultural revolution" (Werner, 2015) and also after the victory of the war in April 1975 (Buswell, 2003, p. 170; Schwenkel, 2017; Tran, 2013). The result hints at a quiet, subtle undercurrent of cultural evolution, of Buddhist influence always lurking in the Vietnamese culture even when it was not officially allowed or publicly declared. The re-emergence of Buddhism in Vietnam took place after 1986 when Vietnam began implementing economic reforms, known as Đổi Mới. The rise in popularity of Buddhism, however, does not mean Vietnam has become a religious country. Some statistics still put Vietnam as "one of the least religious countries in the world" as 

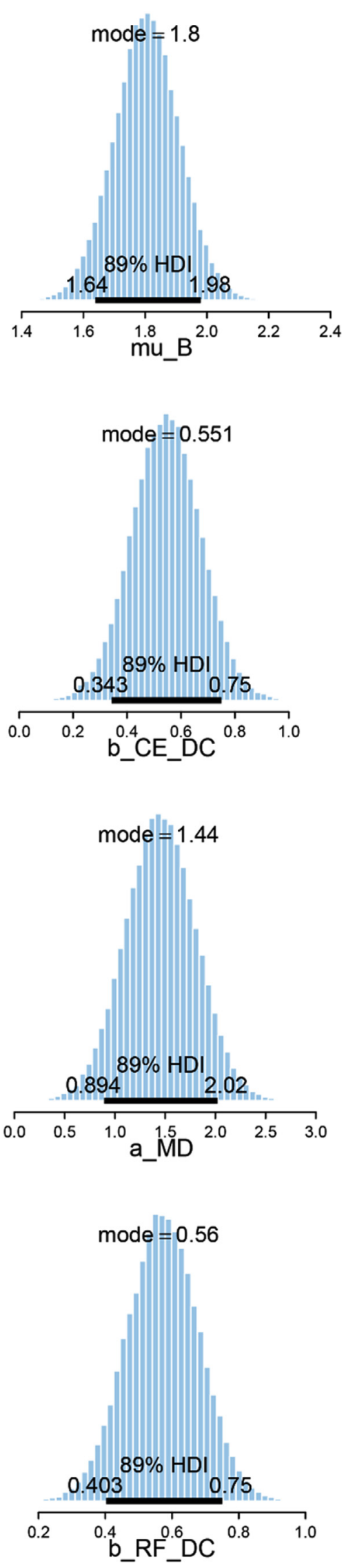
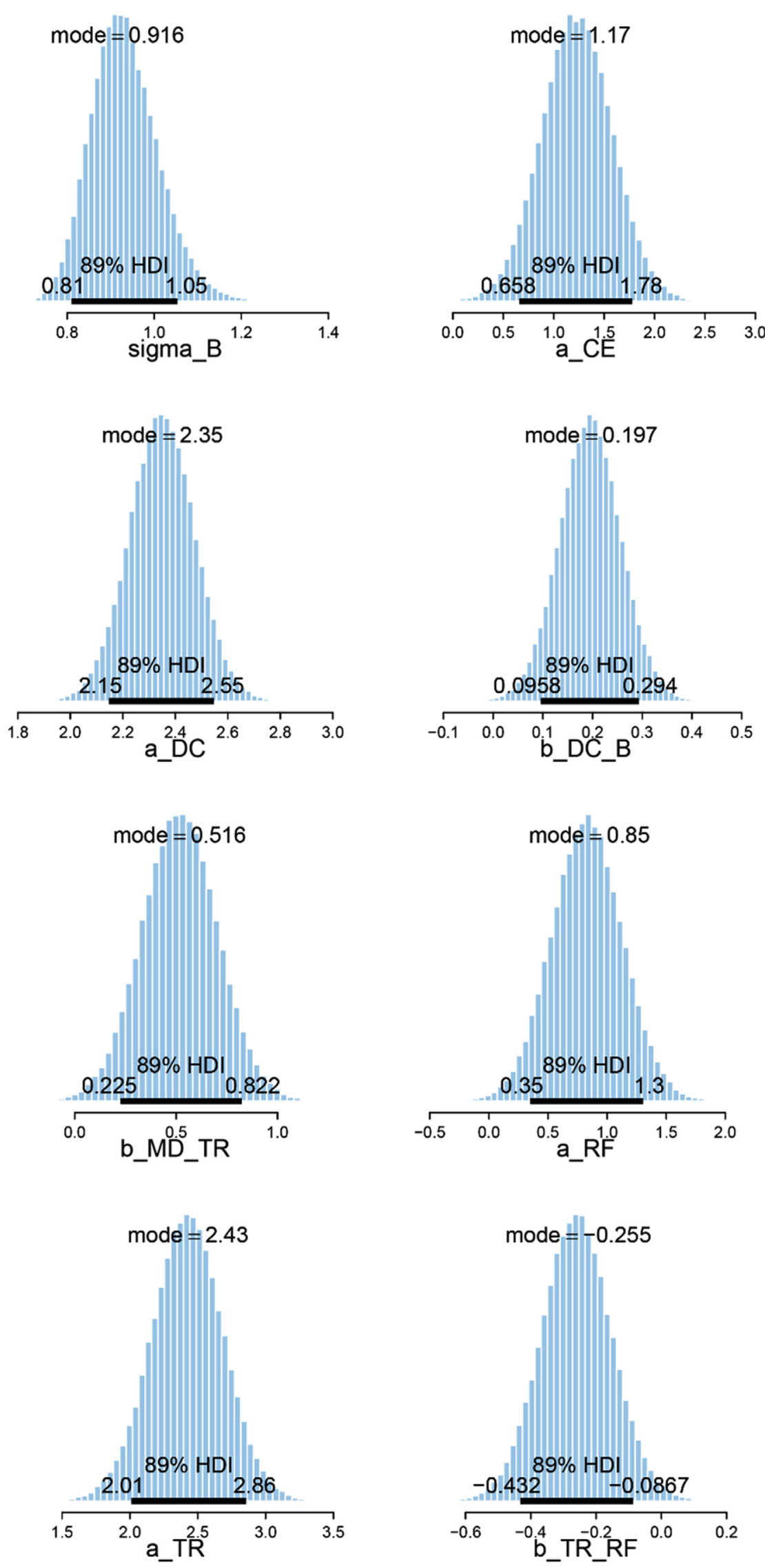

Fig. 9. M13's coefficients' posterior distribution. 
Diagnostics for a.CE
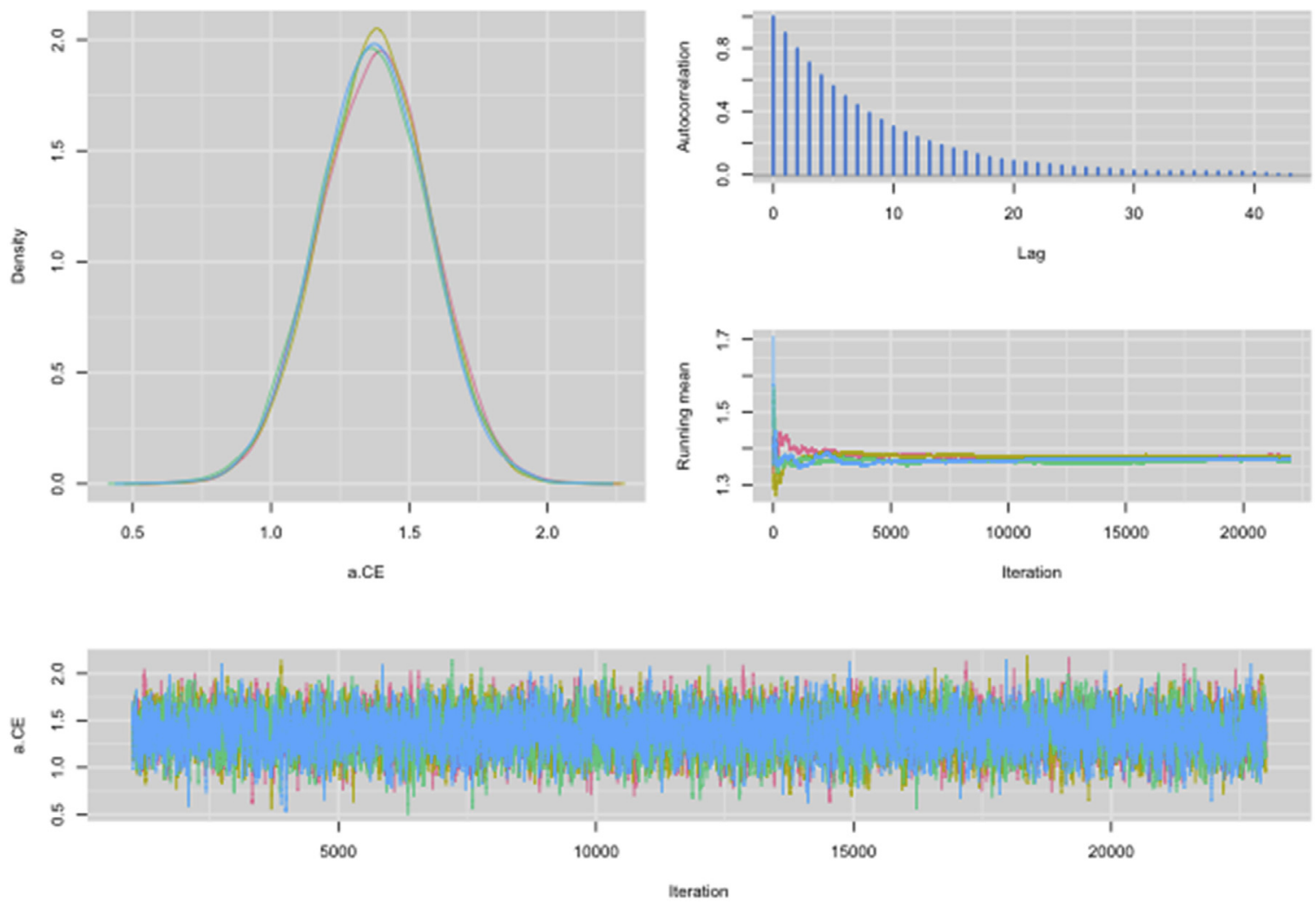

\section{Diagnostics for b.CE}
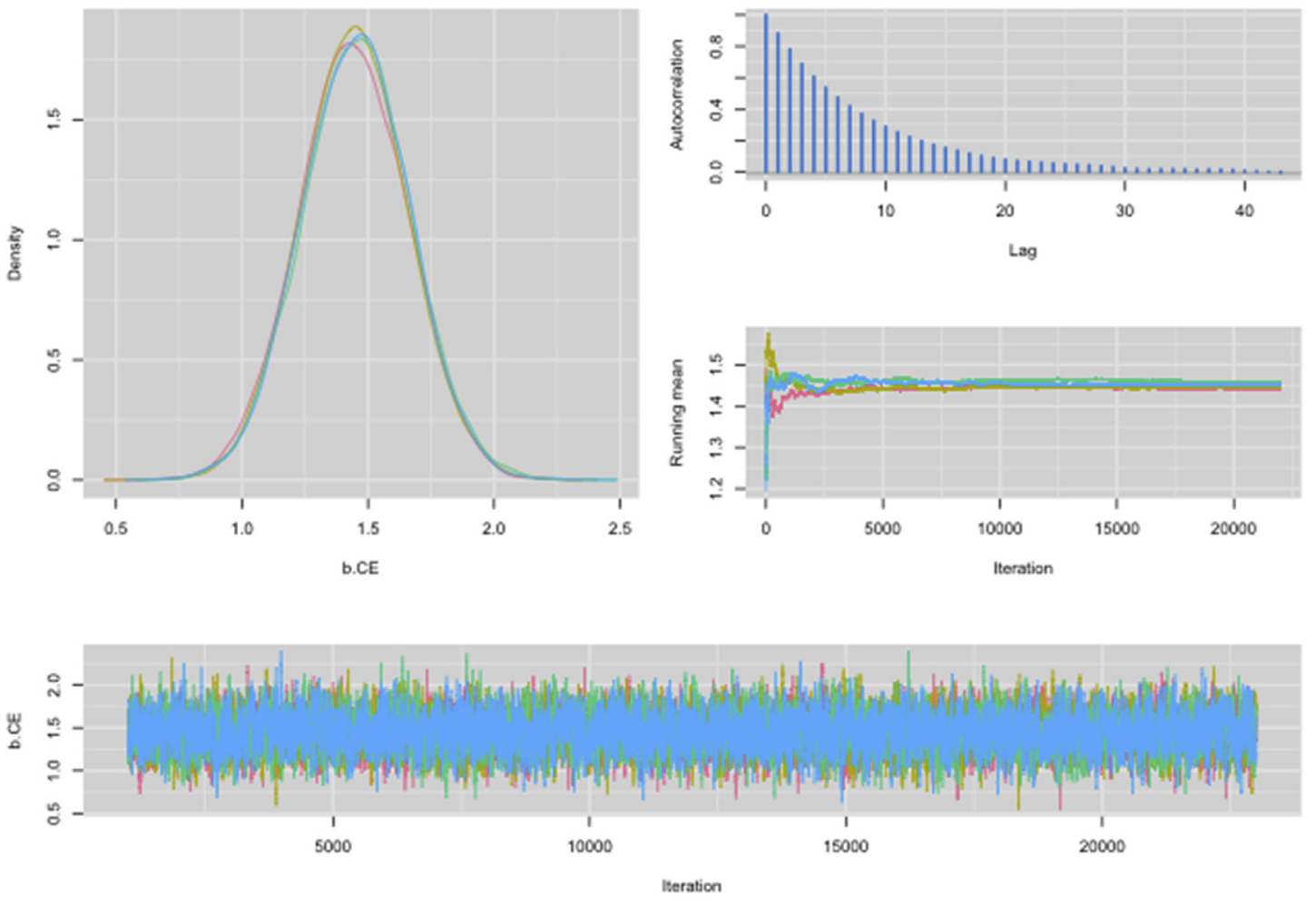

Fig. 10. Hamiltonian MCMC technical validations for $\beta_{\{C E\}}$ in model M13 using JAGS codes. 
the majority of the population declares no affiliation with any religious institution (Hoskins \& Ninh, 2017; Rots, 2017; Vuong et al., 2018b; Vuong \& Vuong, 2018). Though lacking statistical backup, much of the academic literature on Vietnamese religious practices agrees on the highly fervent religious belief and worship in Vietnam, some even characterizing this phenomenon as "widespread re-enchantment" (Rots, 2017; Taylor, 2007). The revitalization of religious practices, particularly Buddhism in the house designs, has gone hand in hand with the country's socioeconomic modernization (Rots, 2017). In fact, thanks to the increasing wealth of a certain class, constructing Buddhist pagodas, or known in Vietnamese as "spiritual tourism destinations," has almost become a profitable business. Bai Dinh Pagoda (Chùa Bái Đính), located in the northern province of Ninh Binh, southeast of Hanoi, is a vivid example of a Buddhist pagoda complex renovated in all its grandeur with the new money-its cost was estimated at USD45 million (Thanh-Nga, 2016).

\section{Conclusion}

The inquiry into the house façade of Hanoi's Old Quarter has brought sharp focus onto the ornamental features and their cultures of influence. The topic itself, as this study shows, has been the subject of numerous qualitative research, yet none has applied Bayesian inference to systematically and rigorously document the selection of such ornamental

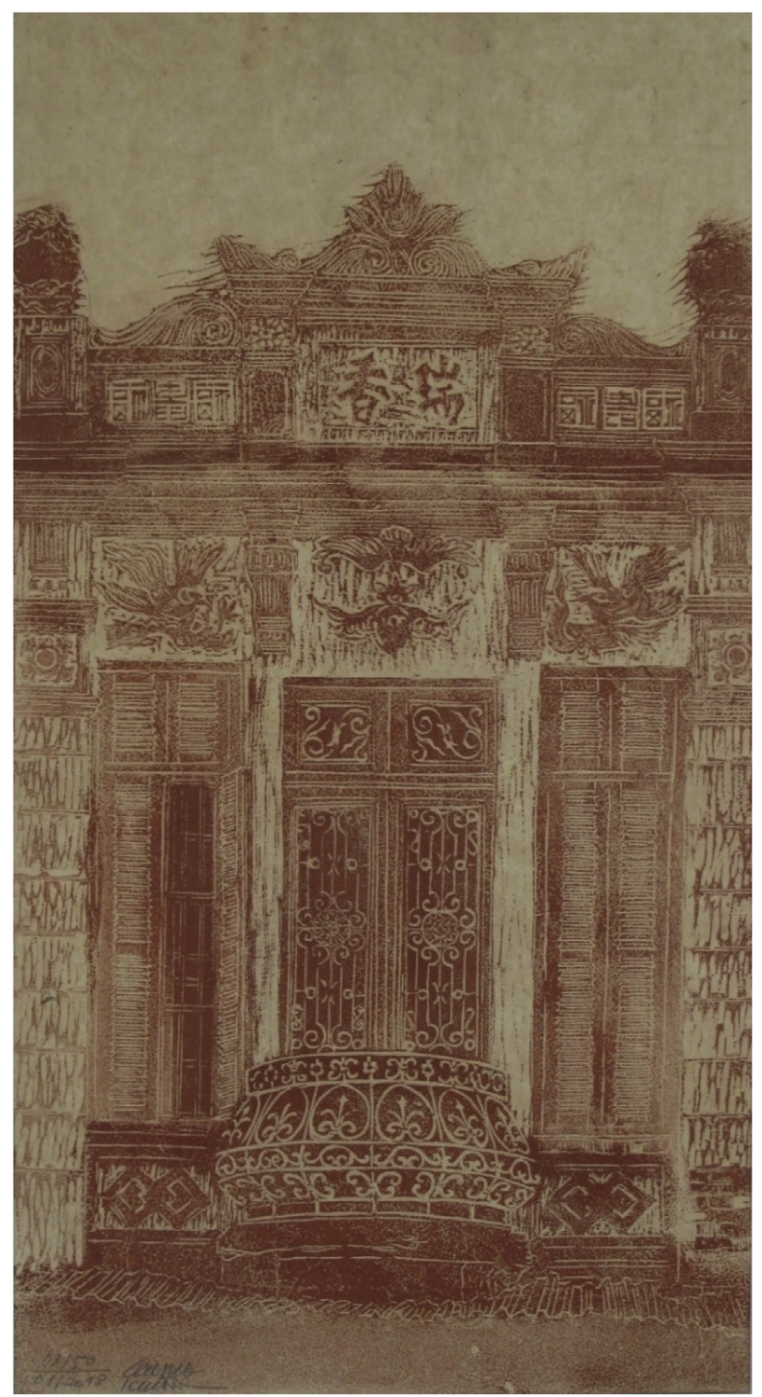

Fig. 11. A linocut painting by courtesy of Bui Quang Khiem. designs and the perceived source of cultural influence. This study, therefore, opens up a new approach for social sciences in general and for the study of cultural evolution and architectural transformation in particular.

If Vietnamese fine art has intrigued myriad art collectors and researchers for its mixture of Southeast Asian artistic traditions since the early 20th century—such as the use of bright colors and dominant themes of farmland and countryside (Taylor, 2009)—and French colonial legacy (Vuong et al., 2018a), then its architecture has also captivated artists and ordinary people alike. Inspired by the spirit of Bui Xuan Phai and his immortalized paintings of Hanoi old streets, this study hopes to invite scholars of Vietnam studies as well as the international community to join the discussion on novel quantitative methodology in architecture studies and social sciences at large.

For closing this inquiry, the paper would like to end with a linocut painting by the artist Bui Quang Khiem (Fig. 11). The picture, based on an actual photo taken by the artist for this research, shows the façade of an old house on Cau Go street in Hanoi that exemplifies the mixing of many features of different architecture styles, such as the prominent Chinese characters at the center of the pediment, the two lotus flowers on the top columns, the art décor window and balcony iron railings, the French shuttered windows, to name a few. Just as the house in this linocut print stands immortalized on paper, the 500 photos taken for this research project (of which 278 were used) have locked in the shape and form of Hanoi houses at a specific point in time. In a city that is bustling with constant movements, the photos freeze Hanoi and its unique fusion of foreign architectural elements in time just enough for this academic inquiry to set off.

\section{Conflict of interest}

The authors declare no conflict of interests.

\section{Appendix A. Supplementary data}

Supplementary data to this article can be found online at https:// doi.org/10.1016/j.ssaho.2019.100001.

\section{References}

André-Pallois, N. (2016). École Supérieure des Beaux-Arts de l?Indochine. Taylor and Francis. https://doi.org/10.4324/9781135000356-REM1401-1. Routledge Encyclopedia of Modernism, Available: Taylor and Francis.

Blackmore, S. (2006). Why we need memetics. Behavioral and Brain Sciences, 29(4), $349-350$.

Boyd, R., \& Richerson, P. J. (1996). Why culture is common, but cultural evolution is rare. In Proceedings of the British academy (pp. 77-94). Oxford University Press.

Boyd, R., \& Richerson, P. J. (1985). Culture and the evolutionary process. Chicago: University of Chicago Press.

Bui, X. P. (2012). Hanoi [Painting]. Available at: https://www.wikiart.org/en/bui-xua n-phai/hanoi. (Accessed 22 January 2018).

Bui, T. P., \& Tran, H. T. (1998). Bùi Xuân Phái: Cuộc đời và tác phẩm [Bui Xuan Phai: His life and works]. Hanoi: Nhà xuất bản Mỹ thuật.

Buswell, R. E. (2003). Encyclopedia of Buddhism. Michigan: Macmillan Library Reference.

Cavalli-Sforza, L. L., \& Feldman, M. W. (1981). Cultural transmission and evolution: A quantitative approach. Princeton, NJ: Princeton University Press.

Chiung, W. T. (2007). Language, Literacy, and Nationalism: Taiwan's Orthographic transition from the perspective of Han Sphere. Journal of Multilingual and Multicultural Development, 28(2), 102-116.

Chu, Q. T. (2003). Kiên trúc dân gian truyền thống Việt Nam [Vietnam's Traditional Folk Architecture]. Hanoi: Nhà xuất bản Mỹ thuật.

Claidière, N., \& André, J.-B. (2012). The transmission of genes and culture: A questionable analogy. Evolutionary Biology, 39(1), 12-24.

Clementin-Ojha, C., \& Manguin, P.-Y. (2007). A century in Asia: The history of the École française d'Extrême-Orient 1898-2006. Paris, France: École Française d'Extrême-Orient.

Crema, E. R., Edinborough, K., Kerig, T., \& Shennan, S. J. (2014). An approximate Bayesian computation approach for inferring patterns of cultural evolutionary change. Journal of Archaeological Science, 50, 160-170.

Dediu, D. (2009). Genetic biasing through cultural transmission: Do simple Bayesian models of language evolution generalise? Journal of Theoretical Biology, 259(3), 552-561.

Dennett, D., \& McKay, R. (2006). A continuum of mindfulness. Behavioral and Brain Sciences, 29(4), 353-354. 
Dinh, Q., \& Groves, D. (2006). Hanoi architecture: Some observations by a local and a tourist. Journal on Cultural Patrimony, 1(2), 121-133.

Ellen, M. (2004). The architecture of imperialism. Leiden, The Netherlands: Brill.

Fuentes, A. (2006). Evolution is important but it is not simple: Defining cultural traits and incorporating complex evolutionary theory. Behavioral and Brain Sciences, 29(4), 354-355.

Gill, J. (2002). Bayesian methods: A social and behavioral sciences approach. Chapman and Hall/CRC.

Griffiths, T. L., \& Kalish, M. L. (2007). Language evolution by iterated learning with Bayesian agents. Cognitive Science, 31(3), 441-480.

Hartingh, B. D., Craven-Smith-Milnes, A., \& Tettoni, L. I. (2007). Vietnam style. Hong Kong: Periplus Editions.

Henrich, J. (2004). Demography and cultural evolution: How adaptive cultural processes can produce maladaptive losses - the Tasmanian case. American Antiquity, 69(2), 197-214.

Henrich, J., \& McElreath, R. (2003). The evolution of cultural evolution. Evolutionary Anthropology: Issues, News, and Reviews, 12(3), 123-135.

Herbelin, C. (2016). Architectures du Vietnam colonial: Repenser le métissage. France: INHA/ CTHS.

Higham, C., \& Higham, T. (2009). A new chronological framework for prehistoric Southeast Asia, based on a Bayesian model from Ban Non Wat. Antiquity, 83(319), 125-144.

Hoskins, J. A., \& Ninh, T.-H. T. (2017). Globalizing Vietnamese religions. Journal of Vietnamese Studies, 12(2), 1-19.

Houston, S. D. (1998). In Function and meaning in classic Maya architecture: A symposium at Dumbarton Oaks, 7th and 8th October 1994. Dumbarton Oaks pre-Columbian symposia and Colloquia series. Dumbarton Oaks Research Library and Collection.

Jackman, S. (2000). Estimation and inference are missing data problems: Unifying social science statistics via Bayesian simulation. Political Analysis, 8(4), 307-332.

Jackman, S. (2009). Bayesian analysis for the social sciences. John Wiley \& Sons.

Jordan, P., \& O'Neill, S. (2010). Untangling cultural inheritance: Language diversity and long-house architecture on the Pacific Northwest coast. Philosophical Transactions of the Royal Society B: Biological Sciences, 365(1559), 3875-3888.

Kien, T. (2008a). Conservation pressing task and new documentation of old tube houses in Hanoi Old Quarter through the case of No. 47 Hang Bac Street house. 日本建築学 会計画系論文集, 73(624), 457-463.

Kien, T. (2008b). "Tube house "and "Neo tube house "in Hanoi: A comparative study on identity and typology. Journal of Asian Architecture and Building Engineering, 7(2), 255-262.

Kruschke, J. (2015). Doing Bayesian data analysis: A tutorial with R, JAGS, and Stan (2nd ed.). London, UK: Elsevier.

Kumar, S., Padmanabham, P., Ravuri, R. R., Uttaravalli, K., Koneru, P., Mukherjee, P. A., et al. (2008). The earliest settlers' antiquity and evolutionary history of Indian populations: Evidence from M2 mtDNA lineage. BMC Evolutionary Biology, 8(1), 230.

La, V.-P., \& Vuong, Q.-H. (2019). bayesvl: Visually learning the graphical structure of Bayesian networks and performing MCMC with 'Stan'. The Comprehensive R Archive Network (CRAN) Available at: https://cran.r-project.org/web/packages/bayesvl/i ndex.html. (Accessed 16 July 2019). version 0.8.5 (May 24, 2019).

Le, M. S. (2013). Kiến Trúc Đông Dương [Indochine Architecture]. Hanoi: Nhà xuất bản Xây Dưng.

Lee, S., \& Hasegawa, T. (2011). Bayesian phylogenetic analysis supports an agricultural origin of Japonic languages. Proceedings of the Royal Society B: Biological Sciences, 278(1725), 3662-3669.

Long, T., \& Taylor, D. (2015). A revised chronology for the archaeology of the lower Yangtze, China, based on Bayesian statistical modelling. Journal of Archaeological Science, 63, 115-121.

Malakoff, D. (1999). Bayes offers a 'new' way to make sense of numbers. Science, 286(5444), 1460-1464.

Matthews, L. J., Tehrani, J. J., Jordan, F. M., Collard, M., \& Nunn, C. L. (2011). Testing for divergent transmission histories among cultural characters: A study using Bayesian phylogenetic methods and Iranian tribal textile data. PLoS One, 6(4), e14810.

McElreath, R. (2016). Statistical rethinking: A Bayesian course with examples in $R$ and Stan Boca Raton, FL: CRC Press.

Mesoudi, A., Whiten, A., \& Laland, K. N. (2006). Towards a unified science of cultural evolution. Behavioral and Brain Sciences, 29(4), 329-347.

Mulder, M. B., McElreath, R., \& Schroeder, K. B. (2006). Analogies are powerful and dangerous things. Behavioral and Brain Sciences, 29(4), 350-351.

Naziree, S. (2006). Bui Xuan Phai - the artist of Hanoi. In J. Middelborg (Ed.), Art works by Bui xuan Phai - from the collection of Van Duong Thanh. Bangkok, Thailand: Thavibu Gallery.

Nguyen, T. H. (2014). Kiến trúc Đông Dương là gì? [What is Indochinese architecture?]. Available at: https://nguyenthaihoa317.wordpress.com/2014/01/01/kien-truc-do ng-duong-la-gi/. (Accessed 15 January 2019).

Nguyen, V. U. (2016). Hà Nội nửa đầu thế kỷ XX [Hanoi in the first half of the XX century] (3rd ed. edn). Hanoi: Nha xuat ban Ha Noi.

Oinonen, M., Pesonen, P., Alenius, T., Heyd, V., Holmqvist-Saukkonen, E., Kivimäki, S., et al. (2014). Event reconstruction through Bayesian chronology: Massive midHolocene lake-burst triggered large-scale ecological and cultural change. The Holocene, 24(11), 1419-1427.

Pagel, M., \& Meade, A. (2005). Bayesian estimation of correlated evolution across cultures: A case study of marriage systems and wealth transfer at marriage. In R. Mace, C. J. Holden, \& S. Shennan (Eds.), The evolution of cultural diversity (pp. 245-253). New York: Routledge.

Pagel, M., \& Meade, A. (2006). Bayesian analysis of correlated evolution of discrete characters by reversible-jump Markov chain Monte Carlo. The American Naturalist, 167(6), 808-825.
Paperny, V. (2002). Architecture in the age of Stalin: Culture two (Translated by: Hill, J. \& Barri, R. Cambridge: Cambridge University Press).

Perreault, C., Moya, C., \& Boyd, R. (2012). A Bayesian approach to the evolution of social learning. Evolution and Human Behavior, 33(5), 449-459.

Pham, T. L. (2018). The meaning of Tết in Việt Nam. The Firmament Literacy Journal, 10(4), 8-18.

Phan Cam Thuong. (2008). Nghệ Thuật Ngày Thường [Day-to-day Arts]. Hanoi: Nhà Xuầt Bản Phụ Nữ [Women's Publishing House.

Phan, P. T., Nguyen, T. H., Dao, T. D., Ta, T. H. V., \& Nguyen, T. B. (2017). Khu phố Tây ở Hà Nội nửa đầu thế kỷ XX qua tư liệu địa chính [The Western Quarter in Hanoi in the first half of the XX century via cadastral documents]. Hanoi: Nha xuat ban Ha Noi.

Reali, F., \& Griffiths Thomas, L. (2010). Words as alleles: Connecting language evolution with Bayesian learners to models of genetic drift. Proceedings of the Royal Society B: Biological Sciences, 277(1680), 429-436.

Riede, F., \& Edinborough, K. (2012). Bayesian radiocarbon models for the cultural transition during the Allerød in southern Scandinavia. Journal of Archaeological Science, 39(3), 744-756.

Rots, A. P. (2017). Re-enchantment restricted. In H. Havnevik, U. Hüsken, M. Teeuwen, V. Tikhonov, \& K. Wellens (Eds.), Buddhist modernities. New York: Routledge. https:// doi.org/10.4324/9781315542140.

Schuyler, D. (1984). The eolution of the Anglo-American Rural cemetery: Landscape architecture as social and cultural history. Journal of Garden History, 4(3), 291-304.

Schwenkel, C. (2017). Haunted infrastructure: Religious ruins and urban obstruction in Vietnam. City and Society, 29(3), 413-434.

Scutari, M., \& Denis, J.-B. (2014). Bayesian networks: With examples in R. London and New York: Chapman and Hall/CRC.

Taylor, N. A. (1999). 'Pho' Phai and faux phais: The market for fakes and the appropriation of a Vietnamese national symbol. Ethnos, 64(2), 232-248.

Taylor, P. (Ed.). (2007). Modernity and re-enchantment: Religion in post-revolutionary Vietnam. Singapore: Lexington Books.

Taylor, N. A. (2009). Painters in Hanoi: An ethnography of Vietnamese art. NUS Press.

Thai, B. V. (1994). Masters of Vietnamese painting: To Ngoc Van, Nguyen Gia Tri, Nguyen Sang, Bui Xuan Phai. Hanoi: Fine Arts Publishing House.

Thanh-Nga. (2016). Hé lộ siêu dự án 11.000 tỉ đồng lớn hơn Bái Đính của tỷ phú Xuân Trường ở Hà Nam [Revealing the super-project that costs 11.000 billion VND of the $\mathrm{Ha}$ Nam billionair, Xuan Truong, which is bigger than the Bai Dinh project]. Cafef.vn. Available at: http://cafef.vn/bat-dong-san/he-lo-sieu-du-an-11-000-ti-dong-lon-honbai-dinh-cua-ty-phu-xuan-truong-o-ha-nam-20160222110151486.chn. (Accessed 29 January 2019).

Thouzeau, V., Mennecier, P., Verdu, P., \& Austerlitz, F. (2017). Genetic and linguistic histories in Central Asia inferred using approximate Bayesian computations. Proceedings of the Royal Society B: Biological Sciences, 284(1861), 20170706.

Thu Hang. (2017). Phong cách "kiến trúc Đông Dương" tại Việt Nam đầu thế kỷ XX ["Indochine Style" Architecture in Vietnam in early XX century]. RFI. Available at: http ://vi.rfi.fr/viet-nam/20170324-phong-cach-kien-truc-dong-duong-tai-viet-nam-dauthe-ky-xx. (Accessed 16 January 2019).

Tran, C. T. L. (2013). Communist state and religious policy in Vietnam: A historical perspective. Hague Journal on the Rule of Law, 5(2), 229-252.

Tran Hau Yen The. (2011). Mặt tiền đô thi [Urban facade]. Đề tài khoa học cấp cơ sở [Institute-level scientific research project]. Hanoi: Trường Đại học Mỹ thuật Việt Nam.

Tran, Q. B., \& Nguyen, V. D. (2012). Kiến trúc và quy hoach Hà Nôi thời Pháp thuộc [Hanoi Architecture and Planning under French Rule]. Hanoi: Nhà xuẩt bản Xây Dựng.

Trinh, K. M. (2000). Vài nét về hán nôm học việt nam thế kỷ XX [Some notes on the studies of Han Nom in Vietnam in XX century]. Thông báo Hán Nôm học. Available at: http $: / /$ www.hannom.org.vn/detail.asp?param $=413 \&$ Catid $=420$. (Accessed 20 January 2019).

Truong, N. Q. (2012). Vẩn đề hài hòa Đông Tây trong kiến trúc Đổng Dương ở Việt Nam [On the issue of East-West harmony in Indochinese architecture in Vietnam]. Doctoral Dissertation. Ho Chi Minh City: Đại học Kiến trúc Thành phố Hồ Chí Minh.

TT\&VH. (2010). Nguồn gốc Phái Phố, Phố Phái [The origins of Phai Pho, Pho Phai]. The Thao \& Van Hoa. Available at: https://thethaovanhoa.vn/buixuanphai/details/c471n201 00829010100577/nguon-goc-phai-pho-pho-phai.htm. (Accessed 11 January 2019).

Vietnam Associations of Architects. (2003). Kiến trúc và người Hà Nội [Architecture and Hanoians]. Hanoi: Nhà xuất bản Xây dựng.

Vongvilay, X., Shin, J.-E., Kang, Y.-H., Kim, E. D., \& Choi, J.-H. (2015). The Influence of French colonial rule on Lao architecture with a focus on residential buildings. Journal of Asian Architecture and Building Engineering, 14(2), 279-286.

Vuong, Q.-H. (2014). Vietnam's political economy: A discussion on the 1986-2016 period. Universite Libre de Bruxelles. WP-CEB N ${ }^{\circ} 14-010$

Vuong, Q.-H. (2016). Impacts of geographical locations and sociocultural traits on the Vietnamese entrepreneurship. SpringerPlus, 5(1), 1189.

Vuong, Q.-H., Ho, M.-T., Nguyen, T. H.-K., Vuong, T.-T., Tran, K., \& Ho, T. M. (2018a). "Paintings can Be forged, but not feeling": Vietnamese art-market, fraud, and value. Arts, 7(4).

Vuong, Q.-H., \& La, V.-P. (2019). BayesVL package for Bayesian statistical analyses in $R$. Github. Available at: https://github.com/sshpa/bayesvl. (Accessed 16 July 2019).

Vuong, Q.-H., La, V. P., Vuong, T. T., Nguyen, V. H., Ho, M. T., Nguyen, T. H. K., et al (2018b). Cultural additivity: Behavioural insights from the interaction of confucianism, buddhism, and Taoism in folktales. Palgrave Communications, 4(1), $1-15$.

Vuong, Q. H., \& Tran, T. D. (2009). The cultural dimensions of the Vietnamese private entrepreneurship. IUP Journal of Entrepreneurship Development, VI(3-4), 54-78.

Vuong, T.-T., \& Vuong, Q.-H. (2018). L'Indochine française du XIXe-XXe siècle-politique et religions. Working Paper CEB No. 18-002. Université Libre de Bruxelles. 
Vuong, Q.-H., Vuong, T.-T., Nguyen, H.-K. T., \& Ho, M.-T. (2019). The "same bed, different dreams" of Vietnam and China: How (mis)trust could make or break it. European Journal of East Asian Studies, 18(1), 93-128.

Walker, B. (2011). Indochine style. Singapore: Marshall Cavendish.

Werner, S. J. (2015). God and the Vietnamese revolution: Religious organizations in the emergence of today's Vietnam. In T. T. T. Ngo, \& B. J. Quijada (Eds.), Atheist secularism and its discontents: A comparative study of religion and communism in Eurasia (pp. 29-53). New York: Palgrave McMillan.

Youngblood, M., \& Lahti, D. (2018). A bibliometric analysis of the interdisciplinary field of cultural evolution. Palgrave Communications, 4(1), 120. 